\title{
LOS DERECHOS PÚBLICOS SUBJETIVOS EN LA HISTORIA DEL CONSTITUCIONALISMO ESPAÑOL DEL SIGLO $\mathbf{X I X}$
}

\author{
GONZALO MAESTRO \\ Profesor Titular de Derecho Constitucional \\ Universidad del País Vasco
}




\section{SUMARIO}

1. INTRODUCCIÓN.-2. IUSNATURALISMO Y POSITIVISMO EN LA CONSTRUCCIÓN DEL DERECHO SUBJETIVO.-3. DERECHOS SUBJETIVOS Y DERECHOS PÚBLICOS SUBJETIVOS.-4. LOS DERECHOS PÚBLICOS SUBJETIVOS COMO TÉCNICA DE GARANTIA.-4.1. Los derechos públicos subjetivos como sistema infraconstitucional de definición de derechos.-4.2. Constitución y ley.-4.2.a. La tradición francesa.-4.2.b. La tradición alemana.-4.2.c. La tradición italiana.-4.3. Los derechos públicos subjetivos: su alcance y ámbito de actuación en el constitucionalismo continental del XIX.-5. LOS DERECHOS PÚBLICOS SUBJETIVOS EN EL CONSTITUCIONALISMO ESPAÑOL DEL SIGLO XIX.-5. 1. La recepción española del modelo europeo garantista de los derechos.-5.2. Los derechos civiles de los ciudadanos.-5.2.a. Los derechos patrimoniales.-5.2.b. Los derechos a la seguridad y libertad personal.-5.2.c. Los estados excepcionales.-5.2.d. Las libertades de expresión y espirituales.-5.3. Los derechos políticos.-5.3.a. Los derechos de asociación, reunión y manifestación.-5.3.b. El sufragio.-6. CONCLUSIONES. 


\title{
LOS DERECHOS PÚBLICOS SUBJETIVOS EN LA HISTORIA DEL CONSTITUCIONALISMO ESPAÑOL DEL SIGLO XIX
}

\author{
POR \\ GONZALO MAESTRO \\ Profesor Titular de Derecho Constitucional \\ Universidad del País Vasco
}

\section{INTRODUCCIÓN}

Los derechos públicos subjetivos se han configurado como una categoría central en la cultura jurídica continental, $y$, a pesar de las críticas suscitadas desde su formulación doctrinal, han sobrepasado el cometido y momento históricos en los que fueron propuestos. Sin embargo, su análisis histórico e incluso técnico obliga a situar esta construcción juridica en sus originales propósitos y funcionalizarla a ellos.

Este trabajo pretende abordar los derechos públicos subjetivos en el siglo XIX, especialmente referido al constitucionalismo español del siglo pasado. Es durante este periodo en el que con propiedad ejercieron su función, como construcción dirigida a definir el espacio tasado reservado a la autonomía personal frente al Estado.

El primer problema surge al utilizar una categoría que nace, en su concepción más elaborada, a finales del siglo XIX y se emplea para analizar la vicisitudes jurídicas de la libertad durante todo el siglo. Por otra parte, el origen germano de la teoría plantea el problema de su extrapolación a contextos geográfico-culturales distintos, no sólo a la experiencia continental en general, sino al particularísimo liberalismo español.

En nuestra opinión, tiene legitimidad este planteamiento, en primer lugar, porque el liberalismo continental, a pesar de su pluralismo en 
los procesos de construcción del nuevo orden, hereda una tradición común y por tanto generalizable a sus distintas experiencias. Se trata de los rasgos básicos caracterizadores del absolutismo, modelo este que no se asentó, al menos con esos perfiles, en el mundo anglosajón. El liberalismo continental asumió una lógica de continuidad corregida respecto a ciertos principios de raíz absolutista (prioridad del Estado respecto al individuo, justificación y asentamiento de amplísimos espacios de irresponsabilidad administrativa, etc.) que condicionarán la conformación institucional y la concepción de los derechos en la construcción del nuevo orden 1 .

En segundo lugar, porque las tradiciones doctrinales y los ordenamientos positivos, salvadas las grandes diferencias, en referencia a los derechos, no resultan tan distantes entre Francia y Alemania.

Desde el punto de vista doctrinal, resulta erróneo contraponer como categorías opuestas la concepción de las libertades públicas francesas y la de los derechos públicos subjetivos. Muchos autores han señalado que la propia configuración doctrinal francesa de las libertades públicas fue notablemente tardía ${ }^{2}$, ya iniciado el presente siglo, en un ambiente doctrinal que ya había interiorizado la construcción alemana ${ }^{3}$, que, salvo en algunos casos, nunca se planteó como antitética.

Por otra parte, como veremos más tarde, la construcción estructural de las libertades en el ordenamiento francés no es sustancialmente diferente a aquella alemana.

Cabe así decir que los derechos públicos subjetivos como categoría jurídica se ha universalizado en su aceptación dogmática doctrinal, y en virtud de ello ha pasado a ser el instrumento de análisis de los problemas jurídicos de la libertad personal en nuestra cultura jurídica.

Ciertamente, pueden haber tenido la misma eficacia técnica garantista los derechos públicos subjetivos, en la realidad germánica de finales del XIX, que las libertades públicas francesas durante el siglo pasado, pero ello no invalida el análisis histórico y teórico, en la medida en

1 G. Aмато, Individuo e autorità nella disciplina della libertà personale, Giuffré, Milán, 1976 (reimpresión). págs. 110-121.

2 G. Burdeau, Les libertés publiques, Librairie du droit et jurisprudence, París, 1972. págs. 21-22.

3 También en la misma época, ver M. Hauriou, Précis de droit constitutionel, Recueil Sirey, París, 1929, págs. 624 y 633-637.

Carré Malberg, Contribution à la Teorie generale de l'État, Sirey, París, 1922, tomo II, págs. $440-463$. 
que permite evidenciar una contingenciación de los derechos que se produce de forma distinta. Aunque, ya a finales del siglo XIX, se produce una homogeneización en la concepción política y jurídica de la libertad en el continente ${ }^{4}$.

Desde este punto de vista, se puede compartir la propuesta de AMATO, en especial para el análisis de la libertad en este período. Así, para su comprensión, el problema de la libertad en los ordenamientos liberales debe abordar el análisis de los poderes capaces de penetrar en este $o$ aquel aspecto de la esfera individual ${ }^{5}$, porque éstos son los objetos de atención de los ordenamientos, que definen espacios concretos de actuación del individuo en relación a estos poderes.

La libertad no era, como en la tradición anglosajona, la atribución de una situación jurídica global de tutela de la libertad del individuo contra toda irrazonable restricción, antes bien, estaba constituida por las facultades concretas que en cada momento otorgaba la ley a cada individuo. Este proceso de reducción legal de la libertad era exactamente el núcleo de lo derechos públicos subjetivos. También el punto de llegada de una determinada interpretación política, por ello también jurídica, de los principios revolucionarios de las primeras declaraciones francesas, aparentemente, el polo opuesto de la tradición germánica.

La propuesta de los derechos públicos subjetivos es la traslación al ámbito público de los derechos subjetivos asentados en el derecho privado. El tránsito de una figura que conecta más directamente con la tradición iusnaturalista, a la otra, vendrá facilitada por la dogmática y el positivismo que permitirán depurar estas categorías de referencias iusnaturalistas, metapositivas, posibilitando esa función de contingenciación de la libertad que realizan los derechos públicos subjetivos, desconectando declaraciones de derechos o textos constitucionales de los espacios de libertad reconocidos en cada caso al individuo. Positivismo y dogmatismo que no son ajenos a la centralidad estatista del liberalismo europeo ${ }^{6}$.

Señalado el origen privado de la construcción de los derechos públicos subjetivos, hay que subrayar, no obstante, diferencias funcionales a las distintas necesidades derivadas de la creación de espacios de determinación individual en el ámbito privado y público.

4 M. Fioravanti, Appunti di storia delle costituzione moderne. Le libertà: presupposti culturali e modeli storici, Giampichelli, Turín, 1991, págs. 121-2.

5 G. Амato, Individuo e autorità..., pág. 12.

- G. AMATo, Individuo e autorità..., pág. 11. 
En el caso de los derechos civiles, altamente patrimonializados, el constitucionalismo del XIX incorporó un concepto externo, publicitando sus garantías. Cuando las constituciones definen el derecho de propiedad construyen un espacio general de libertad y precisan los límites de la intervención pública, el reenvío de la propiedad al código, a menudo preexistente, se produce recogiéndose en término idénticos, independientemente de su descomposición en facultades concretas. Resulta un derecho perfecto; se opera, pues, una especie de constitucionalización del código, verdadera constitución de los derechos civiles.

La relación constitución-ley y el papel de ésta no es la misma en los derechos políticos. La distinción fundamental entre derechos civiles y políticos en el liberalismo responden a una distinta intervención de los poderes públicos en estos específicos campos de la libertad individual; también explican las especificidades existentes en el tránsito al derecho público de los derechos subjetivos.

La peculiaridad del liberalismo español del pasado siglo responde más a la profundidad del proceso de contingenciación que opera en su reconocimiento legal, cuando se produce, $y$ al peso real de las soluciones de hecho, alegales, que el poder imponía en la práctica, que a la configuración de un modelo específico. La doctrina española es escasa en lo que a esta cuestión se refiere?, pero la existente, como la mayor de la literatura política, confirma esta afirmación.

Hemos preferido utilizar para el análisis de los derechos en los distintos momentos constitucionales, una clasificación que, en esencia, era la acogida por la doctrina y la literatura politica de la época. Ello por entender que constituia un reflejo de distinciones fundamentales que, por otra parte, no estaban tan alejadas de las clasificaciones realizadas por la más depurada y elaborada doctrina europea. La distinción nítida entre dos grandes categorias de derechos, los civiles y los políticos, es una dìferenciación ideologizada que expresa las distintas exigencias de las esferas de la política y la sociedad. Estaba ya presente en la Declaración revolucionaria francesa, con su distinción entre derechos del hombre y los del ciudadano, y encuentra su consagración positiva en el Código civil napoleónico, que unifica los derechos no políticos en la categoría de derechos civiles ${ }^{8}$.

7 F. TOMÁS Y VALIENTE, "Apuntes para una nueva historia del Constitucionalismo en España", Sistema, 1977.n. 17-18, págs. 71 y ss.

\& L. FerRajol,, "Citadinanza e diritti fondamentali», en Teoría política, 1993, n. 3 págs. 63 y ss. 


\section{IUSNATURALISMO Y POSITIVISMO EN LA CONSTRUCCIÓN DEL DERECHO SUBJETIVO}

La concepción de los derechos políticos en la Europa continental del siglo pasado ha estado marcada por una acusada devaluación de las declaraciones constitucionales, que denota un progresivo tránsito del iusnaturalismo al reino de la norma que funda y es espacio de la libertad.

El iusnaturalismo en la construcción de la cultura jurídica liberal representa el momento filosófico legitimante de la nueva experiencia jurídica que, como tal, presidió las primeras elaboraciones de las categorías jurídicas fundamentales, que tuvieron mayor eficacia en el ámbito del derecho privado.

La concepción del derecho subjetivo, sobre la que se asienta juridicamente la defensa de la libertad, expresa el tránsito de una determinada concepción de los derechos a otra que será más funcional y realmente imperante en el liberalismo, especialmente en Europa Continental. Toda referencia a la idea de derecho subjetivo obliga a remontarse al iusnaturalismo y al iluminismo, fundamentos filosófico-políticos de las revoluciones liberales ${ }^{9}$. El hombre resultaba ser portador de derechos innatos y ningún vínculo ni autoridad podian limitarlos. Esto suponía el establecimiento de una determinada relación entre el mundo de las normas y el sujeto privado, que predicaba la supremacía de éste como referente absoluto primario y previo. Los derechos innatos estaban considerados como "genéricas formulaciones de exigencias no tanto de la naturaleza, como de la razón humana, válidas como principios reguladores del orden jurídico, la función histórica de la teoría fue la de ofrecer pauta para la reforma de las relaciones entre el Estado y los individuos" 10.

En las nuevas relaciones a instaurar entre autoridad y Estado, el individuo y sus derechos constituían un prius que venía dado, al cual necesariamente debía acomodarse el derecho objetivo. Derecho subjetivo y derecho objetivo representan conceptos, separados de esa relación de dependencia, opuestos difícilmente conciliables".

- P. BARCELlonA, "ll problema del rapporto fra soggeeto e ordinamento", en Scritti in onore di S. Pugliatti, vol. I, Giuffré, Milán, 1978, págs. 45 y ss.

10 W. Cesarini Sforza, voz "Diritto soggettivo", en Enciclopedia del diritto, vol. XII, Giuffré, Milano, 1964, págs. 659 y ss.

"R. Orestano, "Diritti soggttivi e diritti senza soggeto", en Azione, Diritti soggettivi, persone giuridiche, II Mulino, Bolonia, 1978, págs. 115 y ss. También P. BARCELLONA, op. cit. 
El papel reservado a la norma es secundario, puesto que el primario recae en la originalidad natural del derecho subjetivo, del derecho del hombre, que es la fuente del derecho.

La fundación del derecho como sistema de derechos subjetivos, prescindiendo de los ordenamientos positivos, permitía consagrar la plena autonomía del sujeto privado y crear una esfera inviolable del individuo recluida en el ámbito del derecho privado ${ }^{12}$. Hasta cierto punto esto no resultaba una novedad. Ya KELSEN había subrayado la funcionalidad de cierto iusnaturalismo para la creación de límites al poder situados estrictamente en el ámbito del derecho privado, mientras que en el público contribuía a una legitimación del absolutismo ${ }^{13}$. No es de extrañar que doctrinalmente el derecho privado fuera concebido como el derecho por excelencia, cumpliendo además la función de ámbito motor de la ciencia jurídica.

La primacía del sujeto y de los derechos del sujeto, como atributo de aquél, predicados con carácter general, constituyó el soporte filosófico-jurídico de las declaraciones de derechos de finales del XVIII, en especial de la americana. La concepción de los derechos innatos penetró en el discurso sobre el poder del Estado y en la relación Estado-individuo. Sin embargo las bases para una revalorización de la norma, del derecho objetivo, que permitiera pasar de los derechos innatos a los otorgados, como sancionará posteriormente la doctrina alemana, estaban ya presentes.

Como señala CESARINI SFORZA, son las declaraciones americanas las que con mayor fidelidad representan ese momento filosófico del iusnaturalismo y de la concepción de los derechos como innatos. La declaración francesa es deudora de la contribución rousseauniana, que funda las bases de la recuperación del Estado. "Rousseau ha introducido en el pensamiento moderno el punto de partida de una larga evolución del modo de concebir la relación entre Estado e individuo, que aleja definitivamente la ciencia del derecho del subjetivismo iusnaturalista para llevarla a un objetivismo rígido, así teleológicamente estatalista» ${ }^{14}$.

La necesaria alienación, en favor de la comunidad, de los derechos naturales por parte de los individuos desemboca en el reconocimiento de la sumisión de éstos a la ley expresión de la voluntad popular. Esta con-

12 R. Orestano, op. cit.

13 KeLSEN, Teoría pura del derecho, UNAM, Méjico, 1983, págs. 228-232... También Qué es la justicia, Ariel, Barcelona, 1982, págs. 70-83.

14 W. Cesarini Sforza, op, cit. 
cepción de la ley como resultado de un nuevo soberano distinto del individuo está presente en las declaraciones francesas e inaugura un nuevo camino. La concepción de la soberanía y su traslado a la ley es el punto en el cual la Revolución francesa media entre iusnaturalismo y estatalismo, marcando la inflexión a este último como fuente de derechos ${ }^{15}$.

Más allá de las bases filosóficas señaladas, aunque con una innegable acogida jurídica, este proceso de objetivización del derecho tiene claras plasmaciones a nivel doctrinal en la propia evolución del concepto central de la concepción jurídica iusnaturalista, el derecho subjetivo. Igualmente, en el derecho positivo, el movimiento codificador aportará un cambio sustancial en la situación. Ambos expresan las nuevas necesidades postrevolucionarias del liberalismo y de la construcción del capitalismo.

En el ámbito doctrinal hay que advertir la innegable contribución a la evolución conceptual del derecho subjetivo, de las actitudes metodológicas de la dogmática que afirmaron el positivismo y la centralidad de la norma como nuevo paradigma científico en el mundo jurídico ${ }^{16}$.

Aunque en la pandectística algunos habían señalado una revalorización positivista ${ }^{17}$, el principio de la ruptura de la concepción iusnaturalista del derecho subjetivo cabe situarlo en la aceptación de la propuesta de IHERING en clave de contraste con la concepción de SAVIGNI.

El derecho subjetivo concebido como "el poder de la voluntad del sujeto" permitía afirmar la prioridad del sujeto, el derecho existía a causa de la libertad del individuo, y era la voluntad del sujeto el origen y motor de la norma. IHERING supone un punto de inflexión. Ahora el derecho subjetivo es el "interés jurídicamente protegido", y esta nueva concepción permite trasladar el centro de la fórmula de la voluntad del sujeto a la voluntad de la norma ${ }^{18}$. No es el sujeto la fuerza creadora, sino el ordenamiento quien reconoce el derecho. El elemento determinante de la concepción de IHERING, para C. SFORZA, reside en la expresión “jurídicamente protegido" que implica un reconocimiento por el ordenamiento

15 M. Fioravanti, op. cit., pág. 55.

16 R. Orestano, op. cit.; también P. Barcellona, I soggetti e la norme, Giuffré, Milán, 1984, pág. 83-4. pág. 37.

17 W. WILHELM, Metodologia giuridica nel secolo XIX, Giuffré, Milán, 1974,

18 R. Orestano, "Persona e persone giuridiche nell'età moderna", en Azione, diritti soggetivi, persone giuridiche..., op. cit., págs. 191 y ss.; ver también V. FroSINI, "Diritto soggettivo e dovere giuridico", en Raccolta dicritti in onore di A. C. Jemolo, vol. IV, Milán, Giuffré, 1963, págs. 2007 y ss. 
del Estado". Así se llega a reconocer que el ordenamiento jurídico del Estado está constituido estáticamente por un complejo de esquemas abstractos de volición y acciones y de su concreción lógica de un solo sujeto volente (el Estado persona). Únicamente según tales esquemas los ciudadanos deben realizar sus fines... de otra forma, su voliciones y acciones quedan fuera del ordo ordinatus" ${ }^{19}$.

Las matizaciones o adiciones realizadas a la definición de IHERING hasta la elaboración de JELLINEK confirman la inflexión realizada. El derecho subjetivo abandona su impronta iusnaturalista aceptándose ahora el primado de la norma. La formulación de los derechos públicos subjetivos supone la culminación de este proceso, donde se afirma con claridad el carácter de otorgado por el ordenamiento al derecho subjetivo.

Si la evolución doctrinal acontece en la doctrina germánica durante la segunda mitad del XIX, la revalorización de la norma en la cultura jurídica francesa y en otros países europeos se operó de manera evidente como consecuencia del movimiento codificador. La codificación expresaba la nueva racionalidad en el comportamiento del Estado, la previsibilidad, a la vez que actuaba la igualdad formal, en definitiva, coadyuvaba al funcionamiento del mercado, y eso sólo era posible mediante el reconocimiento del primado de la ley. Con la positivación de los derechos se resuelve la tensión entre derechos innatos y derecho objetivo en favor de los últimos ${ }^{20}$.

Paralelamente a estas vías, nuevas exigencias políticas imponían el tránsito de los derechos innatos al fortalecimiento del Estado. El iusnaturalismo revolucionario cumplió su papel de fundamento teórico de un modelo político en ruptura con el orden absoluto. Sentadas las bases del Estado liberal y avanzada la construcción de éste, la afirmación del iusnaturalismo carecía de sentido, cuando no era disfuncional con el propio proyecto liberal ${ }^{21}$. "La burguesia no tiene ya necesidad de los "derechos naturales innatos" para contestar el poder político paralizado de las clases aristocráticas feudales, después de haber producido el propio derecho igual, de haber creado el propio poder político, el propio Estado. No existe ya la contraposición entre burguesía y Estado..., tenía así el interés de que fuese garantizada una cierta estabilidad de las relaciones pri-

19 W. Cesarini Sforza, op. cit.

20 Guido Fasso, Storia della filosofia del diritto, vol. III lottocento-novecento), II Mulino, Bolonia, 1970, pág. 29; también P. BARCELlonA, "Rapporto fra sggetto...", op. cit.

${ }_{21}$ V. Frosinl, "Le transformazioni sociali e il diritto soggettivo", en Studio in onore di F. Santoro Passarelli, vol VI, E. Jovene, Nápoles, 1972, págs. 421 y ss. 
vadas y sentía la necesidad de que fuera reconocida una mayor autoridad al Estadon" ${ }^{22}$.

Quedaban asi asentadas las bases políticas y jurídicas para realizar una contingenciación de los derechos innatos, a través del mecanismo positivador, con la devaluación de las declaraciones de derechos que expresaban la conexión con ese momento filosófico aludido.

\section{DERECHOS SUBJETIVOS Y DERECHOS PÚBLICOS SUBJETIVOS}

Si la transformación del derecho subjetivo en el Estado liberal permitía franquear la puerta a los derechos públicos subjetivos, tal y como se formularon en la doctrina alemana a finales del siglo pasado, la relación Estado-ciudadano en el ámbito público precisó también de una neta distinción de estas esferas.

A pesar de la evolución registrada, el derecho subjetivo contribuyó eficazmente a afirmar un espacio de autonomía en el ámbito privado, es decir, en las relaciones intersubjetivas, donde la autonomía se expresa en relación con los otros iguales, sin colisión con la autoridad. Sin embargo, aun extrapolándose la construcción al ámbito público, los efectos de la misma no fueron iguales.

FROSINI evidencia que la necesidad de distinguir entre derechos subjetivos, en sentido propio o privados, y derechos públicos subjetivos obedecía a la notable diferencia entre relaciones de distinta naturaleza, las relaciones interindividuales y las relaciones de autoridad ${ }^{23}$. Igualmente, FERRAJOLI ${ }^{24}$ cree inexcusable distinguir los derechos patrimoniales donde el sujeto evidencia una situación de poder, y los derechos de libertad, conectando con esta distinción el distinto comportamiento del estado liberal, pasadas los fervores iusnaturalistas.

La necesidad de distinguir y sancionar un comportamiento distinto en el ámbito privado y público aparece clara si se advierte la dialéctica liberal entre igualdad formal y desigualdad real, que funda el funcio-

22 P. Barcellona, "Rapporto fra soggetto...", op. cit.

23 V. FrosinI, "Le transformazioni sociali...", op. cit.

${ }^{24}$ L. FerRAJOL, Diritto e ragione. Teoria del garantismo penale, La terza, Bari, 1991, págs. 955-8. 
namiento del sistema. Igualdad y desigualdad que no aparecen contradictorias si se conectan con el papel reservado al Estado. Gobierna la desigualdad en las relaciones de autoridad y la igualdad formal con el espacio de autonomía reconocido al privado en las relaciones intersubjetivas. La estructura contradictoria del Estado liberal viene exigida por esta necesidad de un doble comportamiento ${ }^{25}$.

El Estado garantiza el libre desarrollo de las relaciones económicosociales, caracterizadas por relaciones de desigualdad real, organiza paralelamente las relaciones Estado-individuos, en clave de autoridad: "La regulación de la acción administrativa era fuertemente autoritaria: se expresaba en actos que incidian en profundidad sobre los derechos de los privados, también sobre los derechos constitutivos de la libertad civil y política garantizados constitucionalmente» ${ }^{26}$. El carácter autoritario del Estado liberal queda evidenciado incluso en la forma en que tardíamente se sancionan los derechos públicos subjetivos. Lejos de la definición privatista, el derecho no es un interés del sujeto jurídicamente protegido, sólo es protegido el interés si se registra la coincidencia entre interés general (interés del Estado) y el interés del sujeto privado, limitando el alcance de la libertad ${ }^{27}$. El reconocimiento del interés individual lo es en interés público y no como personalidad aislada, sino como miembro de la comunidad, al menos en los derechos políticos. Si básicamente en los derechos de libertad la declaración general debe venir complementada por la definición de sus límites, es la determinación de estos límites o de las condiciones que legitiman las limitaciones, las que definen los contornos del derecho. Estos límites, que establecen el espacio de autonomía individual, resultan decisivamente comprometidos con semejante concepción del derecho público subjetivo. Con razón señala FERRAJOLI que esta fase histórica es "un capítulo entre los más importantes y desoladores de la involución estatista y autoritaria realizada en el siglo pasado por el pensamiento liberal» ${ }^{28}$.

Así pues, a la nueva realidad político social que surge del Estado liberal ya constituido corresponde una concepción de los derechos que predica una centralidad del Estado en el ámbito público ${ }^{29}$, que está presente desde el mismo surgimiento doctrinal de los derechos públicos subjetivos.

25 P. Barcellona, I soggetti e le norme, op. cit., pags. 124-125 y 131.

26 M. S. GIANNINI, I/ pubblico potere, II Mulino, Bolonia, 1986, pág. 48.

27 A. Esteban DraKe, El derecho público subjetivo como instrumentación técnica de las libertades públicas $y$ el problema de la legitimación procesal, Civitas, Madrid, 1981 págs. 31-37.

${ }_{28}$ L. FERRAJOLI, Diritto e ragione..., op. cit., pág. 57.

29 F. TESSITORE, "Crisi e traformazione dello stato", Recerche sul pensiero giuspubblicistico italiano tra otto e novecento, Giuffré, Milán, 1988, págs. 177-189. 
El proceso de contingenciación de los derechos, en el ámbito público, a través de su positivización legal es el resultado de esa concepción y de la distinción público-privado que se opera en el universo jurídico liberal.

\section{LOS DERECHOS PÚBLICOS SUBJETIVOS COMO TÉCNICA DE GARANTÍA}

\subsection{Los Derechos Públicos Subjetivos como sistema infraconstitucional de definición de los derechos}

Si los derechos naturales supusieron el soporte legitimante de las declaraciones revolucionarias y el origen conceptual del derecho subjetivo, en cuanto sustentaban la centralidad del sujeto frente al ordenamiento. Los derechos públicos subjetivos representan la sumisión del sujeto a la norma y la prevalencia de lógica estatista.

Sentada la premisa iusnaturalista, el paso siguiente es articular la concepción del universo jurídico como sistema de derechos subjetivos y como vía para afirmar la autonomía del sujeto, que era funcional a la generalización del mercado como ámbito de intercambio entre sujetos autónomos.

Sin la premisa iusnaturalista la fundación de la autonomía jurídica del sujeto habría resultado más azarosa. Es esta premisa la que permite la desconexión del individuo del poder público. El derecho subjetivo se constituye como la consecuencia lógica para articular ese espacio autónomo (mercado), configurado por individuos libres e iguales.

Generalizadas las relaciones sociales capitalistas, el derecho subjetivo, en sus relaciones con la autoridad, se publifica subordinándose, reconociendo el papel de la autoridad en la protección del sistema.

La elaboración doctrinal de los Derechos Públicos Subjetivos acontece en tiempos notablemente tardíos. El debate en la publicística germana transcurre en la segunda mitad del siglo pasado y la definitiva obra de JELLINEK aparece ya a finales del ochocientos, aunque la construcción del Estado alemán explica cronológicamente la aparición del derecho público germano y la reflexión sobre sus elementos centrales.

La andadura constitucional se inició en Occidente un siglo antes y en la tradición jurídica continental, especialmente la doctrina francesa, 
aun sin el vigor de la formulación alemana se idearon fórmulas que conducian a similares resultados.

Sabido es que desde los inicios del constitucionalismo occidental se siguieran caminos distinto ${ }^{30}$. Por un lado, el americano, que consagra la supremacía del poder constituyente y su fruto, la Constitución, afirmando la posición prevalente y disciplinante de ésta respecto al resto del ordenamiento jurídico. Por otro, el continental europeo, donde la constitución, por condicionamientos específicos en la construcción del Estado liberal, carece de la consideración de norma superior, especialmente en relación con las declaraciones de derechos o a la afirmación esporádica de los mismos.

Sin embargo, las propias necesidades del proyecto liberal exigían el establecimiento de mecanismos que salvaguardaran esferas de libre determinación individual $y$, a la vez, que éstas, en ciertos ámbitos, no resultasen perturbadoras para este proyecto.

La Constitución que nace en los primeros momentos del movimiento constitucionalista como instrumento de ruptura con el absolutismo, expresión del ideario liberal ${ }^{31}$, estaba contagiada del iusnaturalismo revolucionario, especialmente sus declaraciones de derechos. Era entonces preciso trasladar al espacio jurídico legal (ley), el establecimiento de esos espacios de libertad y su protección, donde era posible discriminar y graduar la intensidad de la eficacia de los derechos declarados. Los derechos públicos subjetivos alcanzarían su máxima expresión en aquellos ámbitos de los derechos de libertad en los que se expresase la idea de autonomía del sujeto en el mercado, del sujeto en cuanto individuo del intercambio ${ }^{32}$.

La positivización operada en la Europa continental supone una desiusnaturalización y desconstitucionalización de los derechos. La desiusnaturalización priva a éstos del potencial universalista y absoluto de sus formulaciones revolucionarias; esta limitación del potencial de las propuestas iusnaturalistas viene realizada a través de una operación de formalización y positivación de los derechos expresados en niveles infraconstitucionales y garantizados con mecanismos conexos con el princi-

30 E. García de Enterría, "La constitución como norma jurídica", en La Constitución Española de 1978, Civitas, Madrid, 1981 págs. 97 y ss.

31 Pérez Royo, La reforma de la Constitución. Congreso de los Diputados, Madrid, 1987, págs. 41-2.

${ }^{32}$ A. DI MAJO, "ll diritto soggettivo nell'ideologia dello stato sociale", en Annuar... 
pio de legalidad: «El formalismo jurídico... no es en realidad la manifestación de una iluminación universalista de la conciencia en la coyuntura histórica de $1789{ }^{33}$.

La desconstitucionalización entendida como pérdida de valor de las declaraciones de derechos, relegando su garantía a instrumentos normativos (ley) más dúctiles, que conviven en relación paritaria con el resto de las normas, permite discriminar mejor los espacios de la política y la sociedad, reforzando la lógica de la autoridad en el primero, y reconduciendo los derechos que tutelan la segunda, a la protección del sujeto como protagonista del intercambio en unas relaciones sociales concebidas sobre esa base.

La categoría dogmática de los Derechos Públicos Subjetivos se construye en la doctrina alemana en clave autoritaria, y se recibe con posterioridad en la italiana. Expresa una relación poder-libertad orientada a preservar, en el espacio de la política, la lógica de autoridad ${ }^{34}$. La formulación francesa acaba por recoger similares planteamientos, a pesar de la convivencia contradictoria con las declaraciones revolucionarias de finales del XVIII ${ }^{35}$. Esta relación era posible sobre la base del establecimiento de un sistema de garantías que descansaba en la ley, que definía en cada caso el ámbito reconocido del derecho, instrumento normativo apto para esa operación reductiva y suficiente para proteger los espacios reconocidos mediante el principio de legalidad.

\subsection{Constitución y Ley}

Recordábamos las diferentes vías del constitucionalismo europeo y americano. La restauración monárquica en Europa Continental después de la derrota napoleónica impone una peculiar construcción del Estado liberal que afectará a la constitución, tanto en sus contenidos como en el lugar que ocupará en el ordenamiento jurídico, del que se deriva su acción garantista ${ }^{36}$. En el complejo proceso constituyente de los Estados

33 P. Barcellona, "Stato di diritto e principio democratico", en Democrazia e diritto, 1990 n. 2, págs. 261 y ss.

${ }^{34} \mathrm{P}$. LABAND, Le droit public de L'Empire allemand, V. Giand y E. Briere, edis., París, 1901, tomo 1, págs. 239-50.

${ }_{35}$ S. Romano, "La teoria dei Diritti pubblici subbietivi", en Tratado di diritto amministrativo, a cargo de V. E.Orlando, S.E.L., Milán, 1897, cap. 1, págs. 2 y ss.

36 E. García de EnTERria, "La Constitución como norma jurídica", op. cit. 
Unidos, los Estados conformaron un concepto de constitución integrado por dos elementos: la declaración de derechos y la forma de gobierno; la declaración adquiría el carácter de fundamento constitucional en esta tradición ${ }^{37}$. Se establecía ya entonces una concepción privilegiada de los derechos. La Constitución federal, aunque en su original redacción se configuró como Frame of Government, ya estableció su carácter de norma suprema y la vinculación de los jueces a su contenido ${ }^{38}$. Por otro lado, la Constitución americana no cerraba su contenido de futuro a los derechos, sino que permitía constituirse en sede de acogida y protección de los mismos en virtud precisamente de su tradición previa. Las diez primeras enmiendas, introducidas muy poco después, conciliaron a la Constitución con el doble contenido ya presente en muchas Constituciones estatales (Bill of rights y Frame of Government), extendiendo a los derechos el mecanismo protector que se derivaba de la consideración de norma suprema y la vinculación de los juecés a ella.

La verdadera aportación del constitucionalismo americano es el lugar otorgado a la Constitución en el sistema de fuentes, con los efectos disciplinantes respecto a todos los poderes públicos que ello conllevaba ${ }^{39}$.

Frente a esta concepción se sitúa la tradición constitucional europea del XIX. CARL SCHMITT caracteriza el Estado europeo del ochocientos como "Estado legislativo parlamentario", y esto tenía precisas consecuencias respecto a la relación entre ley y Constitución: "La Constitución escrita del Estado legislativo parlamentario debe limitarse fundamentalmente a reglamentaciones organizativas y procedimentales. Esto corresponde tanto a la relativa neutralidad liberal, cuanto a la absoluta neutralidad funcionalista de un sistema, cuyos procedimientos y métodos quieren permanecer abiertos y disponibles a concepciones, orientaciones, tendencias y objetivos diversos. Por lo demás, para cualquier Estado legislativo es evidente que la Constitución escrita, dirigida a construir un Estado de este género, no prejuzga de ninguna manera la posi-

37 B. Clavero Salvador, "Del lugar de los derechos y la posición de los jueces entre Constitución y Código (1787-1804)", en Introducción a los Derechos Fundamentales, Miniserio de Justicia, Madrid, 1988, págs. 53 y ss.

38 Ver artículo 6. de la Constitución Federal. Esta Contitución y las leyes de los Estados Unidos que se expidan con arreglo a ella serán la suprema ley del país $y$ los jueces de cada Estado.

${ }_{39}$ L. W. LEW, Essays on the making of the Constitution, Oxford U. P., Oxford-New York, 1987, págs. 258 y ss. E. S. CorwIN's, The Constitution, Princeton, U. P., 1978. págs. 221-3. B. SCHWARTz, The great rights of mankind. A history of the american bill of rights, Oxford U. P., New York, 1977, caps 1-4. 
ción del legislador por ella misma sancionada, incluso si es suplida por el legislador por medio de sus propias reglamentaciones" ${ }^{40}$.

La Revolución Francesa parecía adherirse a la concepción americana en su declaración de derechos de 1789 , la famosa concepción revolucionaria de la Constitución integraba tanto la garantía de los derechos como la organización de los poderes (separación). Sin embargo, la declaración fue pronto desmentida por la Constitución, iniciándose una dualidad no integrada, entre declaración de derechos y Constitución, que contagiaría al resto de Europa.

La Constitución Francesa de 1791 introduce una tensión que va a reconocer todo el constitucionalismo europeo del XIX, la tensión CódigoConstitución. Fiel nominalmente a la afirmación revolucionaria, el título I de esta Constitución aborda la garantía de los derechos, pero hace recaer ésta en el Código. En definitiva, se desplaza a un instrumento legal, infraconstitucional, la garantía de los derechos, que es tanto como decir su eficacia. Los derechos existen sólo en los términos expresados en la ley. El código de leyes civiles previsto en la parte final dedicada a las disposiciones fundamentales garantizadas por la Constitución tiene exactamente ese alcance ${ }^{41}$.

Desde los primeros momentos del constitucionalismo europeo se consagra la tensión Código-Constitución y se comienza a configurar a aquél como sede de los derechos.

\section{a) La tradición francesa}

Hemos señalado cómo ya desde el comienzo de la historia constitucional francesa se produce la tensión Código-Constitución. La alusión constitucional al Código como elemento de desarrollo y garantía de los derechos tiene su continuidad en la plasmación normativa del principio de separación de poderes, ya que éste conduce a afirmar la soberanía de la ley. Antes de la Constitución de 1791, el Decreto de 6 de agosto de 1790 establece la estricta sujeción de los jueces a la ley, evitando incluso la interpretación como forma indirecta de participación en el poder legislati-

40 C. Scнмпт, "Legallità e legittimità", en Le categorie del politico, II Mulino, Bolonia, 1972, págs. 211 y ss.

${ }^{41}$ B. ClAVERo, op. cit. También "Garantie des droits, emplazamiento histórico del enunciado constitucional", en R.E.P., 1993 n. 981 , págs. 7 y ss. 
vo. Se consagra la prohibición de los tribunales de impedir o suspender la ejecución de los decretos del cuerpo legislativo sancionados por el rey. Curiosamente, una norma, pre e infraconstitucional, explica cómo se materializa esta relación ley-Constitución.

CRUZ VILLALÓN ha explicado el proceso de degradación de los derechos en el sistema constitucional francés del XIX. Establece tres etapas: la primera, caracterizada por una constitucionalización fracasada, a la que ya hemos aludido; la segunda, por una positivización teórica, y la tercera, por una completa desconstitucionalización de los derechos ${ }^{42}$.

Durante las constituciones de la primera mitad del ochocientos (cartas de 1814 y 1830), las declaraciones de derechos desaparecen conteniendo sólo alusiones a garantías de los derechos. Pero como dice $M$. HAURIOU, la garantía no es un instrumento perfecto que precisa para su eficacia la mediación de la ley, sin la cual no puede ser ejercido aun estando reconocido constitucionalmente ${ }^{43}$.

En opinión de la mayoría de la iuspublicística francesa, las declaraciones de derechos, de contenido filosófico-político, eran declaraciones de principio no operativas en el plano positivo ${ }^{44}$.

La Constitución de 1875, la de más larga duración en la historia constitucional francesa, se limita a la organización de los poderes, careciendo de parte dogmática.

CARRE DE MALBERG define la relación constitución-ley-derechos de forma contundente. "El parlamento, que es el más poderoso de los órganos constituidos, es al mismo tiempo dueño del poder constituyente ${ }^{45}$; más adelante, en relación con los derechos en la Constitución dice: «En particular, ella guarda un silencio completo sobre la cuestión de los derechos o libertades individuales pertenecientes a los ciudadanos

42 P. Cruz Villalón, "Formación y evolución de los derechos fundamentales», en Introducción a los derechos fundamentales, op. cit., págs. 155 y ss.

43 M. Hauriou, Précis de Droit Constitutionel, Recueil Sirey, París, 1929, op. cit., pág. 631 .

${ }_{44}$ M. J. Redor, De l'état legal à l'état de droit. La evolution des conceptions de la doctrine publiciste française 1879-1914, Press Universitaires d'Aix-Marselle, Aix en Provence, 1982, pág. 165.

${ }_{45}$ R. Carré De Malberg, Contribution à la Theorie Generale de L'État, tomo II, Recueil Sirey, París, 1922, pág. 607. 
en su relación con las autoridades constituidas $y$, por consecuencia, ella deja al legislador, en lo que concierne a la reglamentación extensiva o restrictiva de estos derechos un poder ilimitado" ${ }^{46}$.

El mecanismo francés de reconocimiento y protección de las libertades públicas se legaliza abandonando su lugar en la Constitución, si alguna vez lo tuvo.

Resulta esclarecedora la terminología de C. MALBERG para definir el Estado Francés durante el XIX. El Estado legal organiza la supremacía del legislador a través del reino de la ley formal.

\section{b) La tradición alemana}

La Constitución del I Reich ya había resuelto, en lo sustancial, la relación entre poderes. Como ha sido señalado, desde el fracaso de las tentativas liberales en 1848, "la burguesía había renunciado a perseguir hasta el fondo sus aspiraciones políticas frente a los poderes del Estado autoritario" " 4 . El ambiente para un reforzamiento del poder y la precariedad de los límites en el ejercicio del mismo, dentro de los espacios acordados entre monarca y parlamento, explica las peculiaridades del derecho público alemán y de su doctrina.

Con variaciones derivadas de la paulatina incorporación al proceso de unificación alemana bajo la hegemonía prusiana estará sustancialmente vigente desde 1850 hasta 1918, la Constitución prusiana, que devendrá en 1871 Constitución del Reich. En este marco constante del derecho público alemán, la doctrina será unánime respecto a las relaciones ley-constitución. Las consecuencias derivadas de la rigidez constitucional afectarán a las condiciones impuestas para su reforma, pero no al establecimiento de unas relaciones tales que permitan establecer un límite al legislador ordinario.

Para GERBER, como hemos dicho, la sumisión de los derechos a la ley era una condición de su ejercicio ${ }^{48}$ y el término ley no remitía a la

46 R. Carrè de Malberg, op. cit., pág. 608.

47 WALTER WILHELM, Metodologia giuridica nel secolo XIX, Giuffré, Milán, 1974, pág. 146. M. FIoravanti, Giuristi e costituzione politica nell'ottocento tedesco, Giuffré, Milán.

48 Gerber, Diritto Pubblico, Giuffré, Milan, 1971. pág. 124. 
Constitución. El alcance de la distinción que hace entre las distintas leyes, entre ellas las constitucionales, no es el derivado de criterios de jerarquía, sino puramente sociológicos, cuando se refiere a ellos ${ }^{49}$.

La doctrina de finales de siglo es contundente. Cuando O. MAYER se refiere a la ley, lo hace en términos como "la ley es inviolable, la voluntad del Estado que se ha manifestado de esta forma no puede ser abrogada, modificada o invalidada por otra causa" ${ }^{50}$. En similares términos se pronunciará LABAND cuando se refiere a la primacía de la ley como característica de ésta.

Igualmente JELLINEK alude a la dificultad de establecer un criterio jerárquico efectivo cuando al juez se le impide comprobar la concordancia entre las leyes y la Constitución como vía de afirmación de la superioridad de éstas. Dicho principio, en su opinión, se impone en el panorama constitucional europeo ${ }^{51}$.

\section{Tradición italiana}

El Estatuto Albertino de 1848 preside la Italia del siglo pasado y enmarca las relaciones entre poderes constituidos (el legislativo) y la propia Constitución.

Recordando la distinción habitual en los textos constitucionales europeos del XIX, era en la parte dogmática donde se presentaban los problemas de relación entre estos niveles normativos La colisión entre estas normas en el campo de los derechos es resuelta a favor de una primacía efectiva de la ley ordinaria. Así, ROMANO expresamente acepta esta relación: "Está fuera de duda que contra los órganos legislativos y sus actos el súbdito no podrá nunca hacer valer ninguna pretensión para que este límite sea observado: frente al Estado, en cuanto aparece como legislador un derecho de libertad no es admisible... por otra parte, en el derecho italiano, la ley constituye de modo definitivo e incontrolable tal ordenamiento" ${ }^{52}$.

49 Gerber, op. cit., pág 158.

50 O. MAYER, citado por D. JESCH, en Ley y Administración. Estudio de la evolución del principio de legalidad, IEA, Madrid, 1978, pág. 38. 1978. pág. 406.

${ }^{51}$ JelLINEK, Teoría general del Estado, Editorial Albatros, Buenos Aires,

${ }_{52}$ S. Romano, /l diritto pubblico italiano, Giuffré, Milán, 1988, pág. 96. 
En esto, declaraba ORLANDO, el ordenamiento italiano no hace más que seguir una constante que es generalizable a los modernos estados civiles ${ }^{53}$.

La pequeña reseña de las doctrinas publicistas europeas más relevantes tenía por objeto mostrar la homogeneidad de soluciones en una cuestión que se articulaba como requisito necesario para el establecimiento de un sistema de reconocimiento de los derechos como derechos públicos subjetivos, que debía permitir una contingenciación de ellos frente a la formulación revolucionaria de los derechos.

\subsection{Los Derechos Públicos Subjetivos: Su alcance y ámbito de actuación en el constitucionalismo continental del XIX}

Recordábamos al comienzo que los Derechos Públicos Subjetivos nacen doctrinalmente en la Alemania del siglo XIX. En cierto modo, el debate publicista sobre la extensión de los Derechos Subjetivos al ámbito público marca el nacimiento del derecho público alemán. Ello no es de extrañar, puesto que permitía introducir el rigor de las construcciones dogmáticas del derecho privado en el público. Con la idea de los Derechos Públicos Subjetivos se pretendía introducir en las relaciones individuo-Estado una lógica paralela a la existente en el ámbito privado. Los Derechos Subjetivos establecen las reglas de relación intersubjetiva, estableciendo los espacios de libertad y por tanto de actuación de los sujetos privados. Al definir espacios de no injerencia respecto a otros, el Derecho Público Subjetivo pretende lo mismo. Para ello resuelve el problema previo de uno de los sujetos de la relación, el Estado, que a través de la concepción del mismo como persona jurídica la subjetiviza ${ }^{54}$. Desde este punto de vista, tiene razón CASETTA cuando reconduce a una categoría teórico-doctrinal única, perteneciente a la teoría general del derecho los Derechos Públicos Subjetivos y los Derechos Subjetivos ${ }^{55}$. Por ello, también cabe una concepción unitaria, entre el núcleo central de los Derechos Públicos Subjetivos y los Derechos Subjetivos, que puede definirse así: en primer lugar, reconocimiento por una norma de derecho obje-

53 V. E. ORLANDo, "Sulla teoria deí díritti pubblici subbietivi di Jellinek", en Scritti varii (1881-1940), Giuffré, Milán, 1954, págs. 275 y ss.

${ }^{54}$ JeLlinek, Sistema dei diritti pubblici subbiettivi, Società Editrice Libraria, Milán, 1912, págs. 10-14.

55 E. CASETTA, voz "Diritto pubblici subbietivi", en Enciclopedia del Diritto, XII, Milán, 1964, págs. 791 y ss. 
tivo de un espacio de libre actuación del individuo respecto a su propia persona o a un bien, donde se materializa el núcleo del derecho como interés protegido. Como consecuencia de ello, otorgamiento de su haz de facultades de actuación, que se manifiestan de diferente forma, bien como reacción contra una perturbación, o como ejercicio directo de las facultades, que representa el momento externo de derecho subjetivo constituido por el poder ${ }^{56}$. El mecanismo último de garantía reside en el establecimiento de cauces procesales para la defensa del derecho.

En ambos casos, ámbito privado o público, se pretende preservar espacios de autonomía del individuo.

Las definiciones clásicas de los Derechos Públicos Subjetivos aluden de una u otra forma a estos contenidos. La fórmula «sólo el reconocimiento jurídico de la voluntad de querer dirigida a un interés puede producir la individualización del derecho....... ${ }^{57}$, a lo que se adhiere S. RO$\mathrm{MANO}^{58}$, recoge los elementos anteriores.

La lógica de los Derechos Públicos Subjetivos los reconduce esencialmente a los denominados derechos civiles. Si nos detenemos en las ya clásicas clasificaciones de los Derechos Públicos Subjetivos reconocidos a los individuos, podremos observar con claridad esto. La propuesta por JELLINEK: Status libertatis, civitatis y activae civitatis, evidencia la centralidad dentro de los Derechos Públicos Subjetivos de los derechos civiles. La posterior de ROMANO, que añade los Derechos Públicos Patrimoniales, de hecho, reconoce lo mismo.

El ámbito de los Derechos Públicos Subjetivos en el XIX remite, en lo que a los ciudadanos se refiere, a los derechos de libertad y los políticos. Se trata de ver el alcance que estas formulaciones doctrinales dan a estos ámbitos de derecho reconocidos.

Los derechos de libertad encontraron dificultades conceptuales para abrirse paso en la doctrina. El sector más conservador de la misma representado por LABAND los negaba, considerándolos meros derechos reflejos de las normas objetivas, que eran consecuencia de la autolimitación, soberanamente decidida por el Estado ${ }^{59}$. Las consecuencias de esta

56 R. ALESSI, "La crisi attuale della nozione diritto soggettivo ed i suoi possibili riflesi nel campo del diritto pubblicon, en Rivista Trimestrale di Diritto Pubblico, 1956, págs. 307 y ss.

57 G. JelLINEK, op. cit., pág. 49.

58 S. ROMANO, op. cit.

59 P. LaBAND, op. cit., págs. 239-40. 
concepción eran claras, se permitía declarar a esos derechos como contingentes, es decir, dependían del alcance que en cada caso tuviera la autolimitación del poder. No se configuraba a priori el derecho, sino a posteriori y en los términos derivados de la limitación autodecidida normativamente. Es obvio que el problema era, a través de construcciones jurídicas, reducir el potencial efecto sobre el ámbito político de estos derechos.

La apertura de JELLINEK es en todo caso consciente del problema y brinda una solución que no resuelve definitivamente el problema. Para este autor, sólo muy pocos derechos de esta categoría pueden tener una formulación general y por tanto ese alcance, ello a pesar de ser estos derechos los que mejor se adaptan a estas fórmulas. Reduce éstos a la libertad religiosa, etc., es decir, a aquellos cuyo ámbito de eficacia se materializa en el interior de la persona y tienen reducido efecto social y político. En su formulación, éstos pueden expresarse en términos generales porque el vacío que resulta de la abolición de las disposiciones restrictivas es el efecto querido por el legislador ${ }^{60}$. En su opinión, «la libertad sancionada incondicionalmente podría tener como consecuencia subvertir todo el Estado... Corresponde al legislador dar un contenido concreto para el cual no es posible encontrar una fórmula que tenga valor general ${ }^{61}$.

Porque la intención no es el reconocimiento de la libertad como situación global de tutela ${ }^{62}$, sino el establecimiento de un espacio reglado de actuación, con la extensión que la situación aconseje. Esta percepción de los derechos constituye un punto de unión de la doctrina alemana y francesa, con independencia de la intensidad de las formulaciones. "La organización de un derecho tiene por objeto hacerlo relativo $\mathrm{y}$ adaptarlo a las contingencias sociales imponiéndole las restricciones y condiciones de ejercicio necesarias» ${ }^{63}$.

S. ROMANO formula de manera distinta los derechos de libertad, pero, como hemos visto en la relación ley-constitución, el resultado es coincidente. Para ROMANO, los derechos de libertad comprenden múltiples aspectos, de tal forma que resulta imposible tabularlos, más aún, resulta inútil, su existencia no se deriva de su enumeración en una carta constitucional, éstos son extraíbles del contexto de la legislación ${ }^{64}$, con lo

60 Jellinek, Sistema dei diritti..., op. cit., pág. 108.

61 JeLLINEK, op. cit., pág. 115.

62 G. Amato, op. cit., pág. 11.

631.

63 M. Hauriou, Précis de droit constitutionel, Recueil Sirey, Paris, 1929, pág.

${ }_{64}$ S. Romano, "ll diritto pubblico subbietivo"..., op. cit. 
cual, es la legislación casuística la que marca sus perfiles. Su intento de enunciar un concepto global de derecho de libertad, en singular, que los comprenda a todos, se agota en la lógica doctrinal. Su definición como "facultad concedida a los súbditos de remover los impedimentos interpuestos por un órgano del Estado a una actividad que la ley preserva o por lo menos no prohíbe ${ }^{65}$, remite a una doble cuestión. La primera está incorporada a la definición, la manifestación concreta del derecho de libertad está establecida en la norma. Libertad como posibilidad de hacer lo que la ley autoriza. El derecho de libertad único queda convertido en las particulares concesiones legales ${ }^{66}$. La segunda se refiere a las garantías del derecho, en los términos de su definición, a los instrumentos para remover los impedimentos. La garantía concebida en última instancia como protección jurisdiccional sólo se materializa en los términos concretos delimitados normativamente (legalmente). Este marco legal estricto es la materialización del principio de autolimitación del Estado y "dentro de los límites de esta carga, el súbdito debe prestar perfecta obediencia» ${ }^{87}$.

Respecto a los derechos políticos, la coincidencia en términos doctrinales es aún mayor. La constante en todos los autores es señalar la tensión entre el carácter de derecho, respecto a la pretensión de los ciudadanos a participar en la vida política del Estado, o su concepción como función, participación en una función estatal. La tensión que en LABAND se resuelve a favor de la función, negando la existencia de Derechos Públicos Subjetivos en este ámbito, en el caso de GERBER, de manera equívoca, su aceptación se limita a ciertas categorías de ciudadanos que conforman la parte no electiva de los órganos estatales ${ }^{68}$. Cuando se admite la existencia de Derechos Públicos Subjetivos de participación política, la tensión entre derecho y función se resuelve concibiendo unos derechos funcionales, se funcionalizan los derechos, se consideran éstos como medio para proveer los órganos del Estado estableciendo una extraña coincidencia entre intereses de los individuos e intereses del Estado. Como dice ROMANO, el ciudadano en este caso deviene órgano del pueblo del Estado ${ }^{69}$.

Esta funcionalización de los derechos políticos permite una mejor justificación de las restricciones de los mismos, al fin y al cabo se trata de derechos muy especiales que existen cuando se alcanza la coincidencia

S. ROMANo, op. cit.

G. Амato, op. cit., pág. 9.

S. Romano, op. cit.

Gerber, Diritto pubblico, Giuffré, 1971, págs. 65 y ss.

S. Romano, op. cit. 
entre intereses del Estado y los particulares ya no definen un espacio personal contra el Estado.

Lo cierto es que aunque los derechos subjetivos y los derechos públicos subjetivos, dentro de éstos, se formularán como una categoría doctrinal unitaria, no actuaron como tal en todos los ámbitos donde fueron afirmados, porque no tenían la misma función en todos los casos.

Respecto a los derechos patrimoniales, la afirmación de los mismos en confrontación con el Estado definen las condiciones necesarias para el funcionamiento de las relaciones económico-sociales del Estado liberal. Es el ámbito real de consagración de la libertad e igualdad formal e impiden al Estado sujeciones en materia de propiedad, relaciones individuales e intercambio en general, en que consistian los vínculos precapitalistas que dificultaban la generalización de estas relaciones ${ }^{70}$.

El derecho subjetivo del individuo, en su relación con el Estado, se constituye de manera perfecta y con los contornos típicos de los derechos de omisión. Se establece el derecho y se define fijando las fronteras de la intervención que establecen el espacio reservado al individuo fruto del deber de omisión impuesto al poder público.

La constitucionalización de estos derechos publicita políticamente el carácter central de los mismos y acoge constitucionalmente los términos del código, sin degradación normativa.

En los derechos patrimoniales, la intervención pública es una intervención organizativa de las nuevas relaciones económico-sociales y por ello garantista.

La perspectiva de los derechos con relevancia en el ámbito político es notablemente distinta. La intervención sobre el individuo es de naturaleza diferente porque su función es otra. Se trata de establecer los términos de la relación entre autoridad y libertad-participación, sobre la base de preservar la primacía de la primera. En este caso, los derechos públicos subjetivos son un compromiso que se resuelve en su carácter contingente, dependiente de las exigencias de autoprotección del Estado. Por ello, la Constitución precede al código (en el sentido de norma legal) y su vigencia depende de la existencia de la ley, que en palabras de HAURIOU organiza los derechos $y$, a diferencia de los patrimoniales, no tienen

\footnotetext{
70 C. DE CABo, La república y el Estado liberal, Tucar Edit., Madrid, 1977,
} pág. 87. 
un contenido definido, sino que se realiza legalmente en el proceso de organización de los mismos.

En cuanto que estos derechos abordan el problema del poder, esta cuestión, en el Estado monoclase excluyente que definía al Estado liberal del XIX, se plantea lógicamente de otra manera. La burguesía, en la construcción del Estado liberal, planteó el problema del poder no en términos de derechos, sino a través de mecanismos institucionales distintos, diferentes según los casos, pero reconducibles al reparto del poder. Separación de poderes y soberanía, con la consecuencia de la primacía de la ley, en el caso francés. Principio monárquico y reserva de ley respecto a la cláusula de libertad y propiedad, en el caso alemán.

Más allá del inicial carácter filosófico de las primeras declaraciones, el planteamiento real de los derechos se sitúa en la fase de democratización del Estado liberal en los comienzos del tránsito del Estado monoclase al Estado pluriclase.

Es cierto que estos procesos tienen distinta plasmación según los casos y que las formas de construcción del Estado liberal en cada experiencia no son anecdóticas, pero estas afirmaciones pueden sostenerse con carácter general.

Las dos experiencias en principio más alejadas, la francesa y la alemana, no manifiestan tanto rupturas de esta concepción como materializaciones diferentes, que se traducen en el establecimiento de áreas de inmunidad mayores del poder público".

La tradición francesa, huelga decir, estaba basada en unos principios políticos que se articulan en su formulación en clave de ruptura con el orden absolutista. Los elementos que conforman el modelo francés de articulación del Estado liberal son la concepción de la soberanía y la separación de poder, ambos interrelacionados. A través de la concepción de la soberanía tiene entrada el dogma de la voluntad general, expresada por el parlamento. Por ello, la ley deviene expresión de la voluntad general y justifica su absoluta primacía. Así, los derechos se resuelven en la pura legalidad ${ }^{72}$.

El reconocimiento de unos derechos así contingentes estableció también la diferencia entre los derechos patrimoniales y los de alcance

1 A. Esteban Drake, op. cit, págs. 63-67 y 90-95.

72 G. Amato, op. cit., págs. 131-1114. M. Fioravanti, Appunti di storia..., op. cit., pág. 132. 
político. La observación anteriormente realizada respecto a la prevalencia de las primeras y a la relación Constitución-Código resulta estrictamente válida en el caso francés. "La propiedad privada deviene así el inicio y el fin de una parte bastante importante del documento constitucional, con la consecuencia que el derecho privado se introduce permanentemente en el derecho público y lo condicionas ${ }^{73}$.

La temprana aparición del código marcó una diferencia garantista de estos derechos frente a otros derechos personales y políticos, que tuvieron una vida más azarosa y sometida al ejecutivo en muchas ocasiones $^{74}$.

La afirmación de DUGUIT en relación a la falta de garantías eficaces contra las usurpaciones del Estado soberano sobre los derechos de los individuos ${ }^{75}$, aludiendo a ejemplificaciones históricas, en especial durante el segundo imperio, se ve confirmada por HAURIOU en su análisis sobre los derechos individuales, inexistentes, muchos de ellos, durante todo el siglo como consecuencia de la falta de organización legal de los mismos ${ }^{76}$.

Tanto la publicística de la edad de oro francesa, como la doctrina actual señalan los períodos de sombras dilatados en el siglo XIX respecto a los derechos políticos, centrándose los períodos de sumisión al ejecutivo y de menor nivel garantista en las épocas del consulado y de los imperios ${ }^{77}$. Prácticamente hasta la III República no se normaliza una situación que, de alguna manera, unifica en el final del siglo, en torno a un modelo jurídico similar, en las experiencias históricas aludidas, el sistema de derechos del individuo.

Se ha señalado también que las experiencias francesa y alemana, sobre todo en la última época, no resultan tan divergentes. La recepción doctrinal de la teoría de la autolimitación, el positivismo, la importación de la dogmática alemana, sumada a la aplicación de la construcción francesa de la supremacía de la ley, expresión de la voluntad popular, marcan conexiones evidentes ${ }^{78}$.

73 D. CoRRADINI, "ll processo costituzionale nella Francia rivoluzionaria e il dirino privato", en Diritto e stato nella filosofia rivoluzionaria francesa, Giuffré, Milán, 1992, págs. 171 y ss.

${ }_{74}$ M. VolPI, La democrazia autoritaria, II Mulino, Bolonia, 1979, pág. 34. C. DE CABO, La república..., op. cit., págs. 87, 95-102.

75 L. Dugult, // diritto sociale, il dirjtto individuale e la trasformazione dello stato, Florencia, 1950, pág. 61.

76 M. Hauriou, Précis de droit constitutionel, Sirey, París, 1929, pág. 631.

77 Ver C. A. Colliard, Libertés publiques, Dalloz, París, 1982, págs. 64-89.

78 M. J. REDER, op. cit., pág. 83. 
Por otra parte, el asentamiento no sólo político, sino doctrinal, de una concepción restrictiva de los derechos políticos, que se constata doctrinalmente en el debate sobre el derecho de resistencia, permite declarar que la función del ordenamiento es la defensa del orden social contra los perturbadores. Dentro de esos límites puede operar el reconocimiento y las garantías de los derechos políticos ${ }^{79}$.

Salvando las distancias, que las habia, la solución es un punto de llegada común entre la solución francesa y la alemana: «Los derechos públicos subjetivos... venían a coincidir con aquella misma pretensión a ser tratados conforme a la ley.

La conclusión venía a ser similar a aquella a la que había llegado, con menos esfuerzo, el ordenamiento francés, en el cual, por lo demás, la supremacía de la ley era el punto de partida, no aquella conquista progresiva... que fue por el contrario en Alemania» ${ }^{80}$.

Respecto a los derechos patrimoniales, la afirmación de los mismos en confrontación con el Estado definen las condiciones necesarias para el funcionamiento de las relaciones económico-sociales del Estado liberal. Es el ámbito real de consagración de la libertad e igualdad formal e impiden al Estado sujeciones en materia de propiedad.

Se ha visto hasta ahora cómo los ámbitos en los que actuaban los Derechos Públicos Subjetivos por excelencia, lo hacían con notables restricciones, pareciendo evidenciar una contradicción entre la necesidad del reconocimiento del principio de libertad en el campo político, como requisito de funcionamiento del sistema liberal de relaciones sociales $y$ las necesidades de autoprotección del sistema, que tendían a reforzar la lógica de la autoridad. La consecuencia de esta tensión, que se expresa en la contradicción entre liberalismo y democracia, es la escisión de los derechos en dos ámbitos netamente separados. Por un lado, la libertad política, aquella que expresa esos principios en el campo público, en sentido amplio, y por otro, la libertad del privado, que alcanza su máxima expresión en el de los intereses patrimoniales en sentido amplio también, con sus conexiones necesarias.

Esta división permite diferenciar niveles de protección, una protección dura de los derechos patrimoniales, que se traslada al código, en-

79 Ver resumen de las posiciones que al respecto mantenían la mayoría de los publicistas franceses más emblemáticos de la época (Berthelemy, Esmein, Hauriou, Michaud) en M. J. ReDer, op. cit., págs. 165-171.

80 G. Amato, op. cit., págs. 150-151. 
tendido como concepto general y otra débil, que se manifiesta en el ám: bito de la escena política y que permite sus limitaciones, realizada con la técnica de la desconstitucionalización efectiva, realizada a través de los Derechos Públicos Subjetivos. Desde este punto de vista, CLAVERO dice del Código Civil napoleónico que éste supone ya una constitución, con la idea realmente de suplirla ${ }^{81}$, el lugar donde se quiere instalar la libertad es el del Código, no es el de la Constitución. Porque el Código en el siglo XIX europeo era la expresión formal de la constitución material.

\section{LOS DERECHOS PÚBLICOS SUBJETIVOS EN EL CONSTITUCIONALISMO ESPAÑOL DEL SIGLO XIX. ALGUNOS RASGOS GENERALES}

Aún no apartándose del modelo continental descrito en la configuración del sistema de derechos del individuo, el constitucionalismo español del XIX está evidentemente marcado por la reconstrucción liberal del moderantismo español, que conecta políticamente con la involución doctrinaria francesa ${ }^{82}$.

En torno a los postulados del moderantismo hegemónico durante todo el siglo pasado, se puede reconstruir el tratamiento de los derechos durante nuestro constitucionalismo liberal.

No se trata de reconstruir la constitución material del liberalismo español del XIX, sino de destacar ciertos rasgos esenciales de la misma, que deben servir de marco explicativo del tratamiento de los derechos.

Desde los comienzos de nuestra andadura constitucional, el pensamiento liberal conectó la novedad constitucional y la nueva organización política del país con la tradición. Las apelaciones a la Constitución histórica posibilitaban la desconexión de nuestras constituciones con los principios y postulados revolucionarios más potencialmente transformadores.

La tradición (Constitución histórica) como legitimidad constitucional permite renegar de los revolucionarios franceses. Ya MARTíNEZ MARINA manifiesta su distancia con los jacobinos y revolucionarios france-

81 B. Clavero, "El lugar de los derechos...", op. cit.

82 Diez del Corral, El liberalismo doctrinario, Inst. Est. políticos, Madrid, 1973, caps. xxii-xxv. 
ses $^{83}$. Lo que importa en este caso es resaltar la aparición temprana en el liberalismo español de la conexión tradición-constitucionalismo, cuya evolución dará frutos provechosos en los principios del moderantismo.

El germen prendió, y con ARGÜELLES la fusión opera ya efectos reductores respecto al alcance de la Constitución ${ }^{84}$. Su "Examen histórico de la reforma constitucional..." es ilustrativo en este sentido, recoge su ideario transformador limitándolo a las reformas del poder necesarias para un proyecto liberal disminuido, junto a las modificaciones en materia de propiedad necesarias para impulsar el nuevo orden (esencialmente la abolición de los señoríos).

Pero va a ser desde los años 30 hasta la restauración cuando el moderantismo español materialice explícitamente los rasgos definidores del proyecto liberal del $\mathrm{XIX}$, desaparecida ya de entre sus representantes más significativos las conexiones con la Constitución de Cádiz. De hecho, sus posiciones políticas se articularán en abierta ruptura con este texto.

Empezando por la restauración, donde el concepto de Constitución interna aparece de forma expresa, las ideas base giran en torno a las relaciones entre la corona y las Cortes ${ }^{85}$, ambas instituciones consideradas por CÁNOVAS como verdades madre, corazón de la Constitución interna.

Semejante propuesta estaba ya generalizada en la fase previa a la restauración. De hecho, tanto el manifiesto de SANDHURST como, con más detalle, ya en 1876, el Manifiesto de los Notable establecieron el corpus constitucional en esos términos ${ }^{86}$.

83 F. Martinez Marina, "Defensa del autor contra las causas dadas por el tribunal de la Inquisición a sus dos obras, "Teoría de las Cortes" y "Ensayo histórico sobre la antigua legislación de España" ", en Obras escogidas de D. Francisco M. Marina, BAE, tomo CCII, 1969.

${ }_{84}$ A. GIL Novales, "Agustín Argüelles. Los orígenes de la historia de la Constitución", en Pensamiento político en la España contemporánea, 1800-1950, Teide, Barcelona, 1992, págs. 78 y ss.

85 A. Cánovas, Discursos parlamentarios, C.E.C., Madrid, 1984, DS 11 de marzo de 1876. Ver sobre la Constitución interna en Cánovas: E. ÁlvAREZ CONDE, «EI pensamiento político canovista", REP, 1977, n. ${ }^{2} 213-214$, págs. 233 y Ss. SÁNCHEZ Agesta, Historia del Constitucionalismo español, CEC, MAdrid, 1984, págs. 305-308. Diez del Corral, op. cit., págs. 642-647. También J. Varela Suances-Carpegna, la Teoría del Estado en los orígenes del constitucionalismo hispánico, C.E.C., Madrid, 1983, págs. 364-70.

${ }_{86}$ E. Álvarez Conde, "La Constitución española de 30 de junio de 1876 ", en REP, 1978, n.ํ 3, págs. 79 y ss. Respecto al Manifiesto de los Notables, ver M. AR 
La centralidad absoluta de estos principios institucionales ya dice bastante del papel de los derechos en el proyecto de la restauración, que si se cita en el Manifiesto de los Notables es por la proximidad a la Constitución de 1869 y a la importancia que en ella tuvo el debate sobre los mismos, formulándose, a pesar de su redacción, en abierta rupturas con aquellas posiciones constitucionales.

Alrededor del principio de la monarquía hereditaria y de las Cortes se había tejido una fórmula política, explicitada desde ALCALÁ GALIANO, DONOSO CORTÉS o PACHECO ${ }^{87}$ hasta la restauración, que incluía:

Una noción de la soberanía caracterizada ante todo por el rechazo de la soberanía nacional, afirmando, a través de distintas argumentaciones, la soberanía compartida del rey y las Cortes $^{88}$.

La afirmación de un Estado fuerte, concebido sobre la preeminencia del ejecutivo $y$, por tanto, de la supremacía de la corona.

Ejecutivo que no tiene en muchos casos definidos los límites de su actuación. Incluso se llega a fundamentar teóricamente el decisionismo y respaldar las soluciones de excepción ${ }^{89}$.

Con semejante concepción del poder, el lugar ocupado por los derechos en el sistema político del liberalismo español del XIX se resentia notablemente en una doble dirección. Por una parte, la precariedad del contenido reconocido cuando se producía éste y su posterior regulación; por otra, la habitualidad del recurso a las situaciones de hecho para la suspensión de los mismos.

Para la mayoría de los representantes liberales más relevantes de nuestro siglo pasado, los derechos eran materia marginal de tratamiento y éste se realizaba en conexión con su propuesta de Estado fuerte ${ }^{90}$.

TOLA, Partidos y programas políticos 1808-1936, vol. II, Alianza, Madrid, págs. 112115.

87 E. TOMÁS Y VALIENTE, "Estudio preliminar» a las Lecciones de derecho político de J. Fco. Pacheco, CEC, Madrid, 1984.

88 J. Varela SuANCEs-CarPegna, op. cit., págs. 423-4.

89 J. DONOSO CORTÉs, "Discurso sobre la dictadura", en Obras completas, Editorial Católica, Madrid, 1970, vol. II, págs. 305 y ss. Ver también L. DíEz deL CoRraL, op. cit., pág. 583. J. LleIXA, "Una teología política para la contrarrevolución. J. Donoso Cortés", en Pensamiento político, op. cit., págs. 183 y ss. A. Garrorena MoraLES, El Ateneo de Madrid y la teoría de la monarquia liberal (1836-1847), Inst. Est. Polít., Madrid, 1974, págs. 578-610.

90 A. Garrorena Morales, op. cit., págs. 531-34. 
El tercer rasgo a afirmar en esta fórmula política es la especial subordinación, en relación al panorama europeo, de los derechos individuales en las relaciones con el poder.

La doctrina hegemónica, en materia de derechos, era sentar la prioridad absoluta del orden público.

La reflexión doctrinal sobre los derechos, en este período, se realizaba en casi todos los casos desde una posición ambivalente, actuaban tanto como juristas como portavoces políticos. Incluso en los ejemplos académicamente más puros está presente esta doble dimensión ${ }^{91}$. A pesar de ello, pueden establecerse unas referencias doctrinales de carácter general, sin perjuicio de las, en algunos casos, evidentes diferencias existentes entre los diversos autores. Estas coincidencias son, a nuestro juicio, las siguientes:

- La ruptura con la tradición iusnaturalista. Desde el comienzo, la relativización de los derechos individuales es una constante que contrasta con la tradición iusnaturalista europea. La concepción de estos derechos como supremos y anteriores a la ley, propia de aquella tradición, viene combatida como momento de partida para su tratamiento posterior. "Al hablar de ciertos derechos abstractos considerados por algunos como naturales o imprescriptibles en los hombres declaré muchos de ellos falsos a mi entender, impugné otros como mal explicados y peligrosos, insinué que no hay otros derechos políticos que los nacidos de la misma sociedad, ya formada y de las leyes, y condené tales máximas abstractas y vagas como pésima base para sentar en ella la fábrica de las constituciones", decía ALCALÁ GALIANO ${ }^{92}$. Igualmente, en los demás autores, sin un alarde positivista tan expreso, su carácter de instituidos se refleja en la dependencia legal para su reconocimiento ${ }^{93}$, ello a pesar del influjo religioso, presente tan sólo como elemento justificativo del orden social.

- La radical diferenciación en los derechos individuales, entre los patrimoniales y los políticos, confiriendo a estos últimos una posición residual en el sistema español de derechos públicos subjetivos. Si bien és-

91 El carácter de jurista ideólogo de V. SANTAMARIA PAREDEs ha sido puesto de manifiesto por A. ElORZA en "La ideología liberal ante la restauración: La conservación del orden", REP, 1966, n. 147-148, págs. 65 y ss. pág. 279.

A. Alcala Galiano, Lecciones de Derecho político, CEC, Madrid, 1984,

93 V. Santamaría Paredes, Curso de Derecho político, Imprenta Española, Madrid, 1913, págs. 163-164. 
ta es una característica común a todo el liberalismo, la encontramos más acentuada entre nosotros.

La influencia del doctrinarismo francés es notoria y reconocida ${ }^{94}$, la sensibilidad constitucional de un doctrinario como CONSTANT, se olvida en su adaptación española. La tesis de CONSTANT sobre los derechos ${ }^{95}$ aparece desvirtuada, y se pasa, de afirmar la funcionalización de los derechos patrimoniales respecto a las libertades privadas, a predicar la existencia central de los derechos patrimoniales y la única legitimidad del poder para defenderlos.

Si CONSTANT reconocía un papel a los derechos políticos de los ciudadanos, la función de defender a través de ellos sus derechos patrimoniales, constituidos en la esencia de la libertad de los modernos, ahora no son los ciudadanos, sino el Estado quien tiene como misión fundamental la defensa del ámbito privado-patrimonial de la liberad, para la defensa del orden social los derechos políticos, más que exigibles, son un impedimento.

Así, los derechos se dividen en civiles, que consisten uen el amparo y la segura fianza que se da a las personas y haciendas particulares" ${ }^{96}$, políticos y mixtos, que son aquellos civiles que tienen incidencia en el ámbito político cuando se ejercen fuera del estricto ámbito privado-patrimonial.

La distinción pretende afirmar la centralidad de lo derechos civiles que, en su dimensión patrimonial, no resultan afectados por la coyuntura y necesidades políticas $y$, por tanto, nunca diminuye el amparo político que se les concede ${ }^{97}$.

Igualmente, la distinción establece el ámbito personal del disfrute de los derechos, los civiles otorgados a todos y los políticos, que marcan la frontera del acceso al sistema político.

La distinción, aun no portando ninguna novedad, consagra un núcleo de derechos no contingentes, los patrimoniales, y otro, los políticos, sometidos a los imperativos del orden ${ }^{98}$. Así se establece un espacio re-

94 L. Diez del Corral, El liberalismo doctrinario, op. cit., págs. 24-25. A. GArRorena Morales, op. cit., págs. 507-20.

${ }_{95}$ B. Constant, "La libertad de los antiguos comparada con la de los modernos», en Escritos Políticos, CEC, Madrid, págs. 257 y ss.

96 A. Alcalá Galiano, Lecciones de derecho político, op. cit., pág. 280.

97 A. Alcalá Galiano, op. cit., pág. 283. 
sidual y claramente contingente para estos derechos, y otro alrededor del derecho de propiedad, que constituye el núcleo eficaz de los derechos públicos subjetivos.

A la centralidad de la propiedad correspondía, incluso en la concepción de la doctrina española, la centralidad del código en el conjunto del ordenamiento, más en concreto, del civil refugio de este conjunto de derechos ${ }^{99}$.

En el modelo francés, del que participa España, el código debía ser la plasmación del sistema garantista de la propiedad ${ }^{100}$. La función de la Constitución no es definir los derechos patrimoniales y la propiedad que le vienen dados, sino la de garantizar éstos contra el poder público ${ }^{101}$, consagrando el espacio definido en el código. La función del derecho público se concretaba esencialmente en la protección de las instituciones jurídico-privadas ${ }^{102}$.

El código era el refugio de un orden inmutable, no sometido a las incertidumbres políticas, en concordancia con la concepción de la propiedad, derecho absoluto, tanto en su configuración técnica como en su concepción política.

Junto con esta clara división de ámbitos en la eficacia de los derechos individuales, la doctrina española afirma prontamente las relaciones ley-constitución sobre la base del desconocimiento del concepto constitucional de ley superior. Afirmando la supremacía de la ley con argumentos de pragmatismo realista. La relación entre poder constituyente-poderes constituidos se resuelve proclamando la superioridad del poder constituido, que en definitiva no es más que la derivación de la concepción de la soberanía compartida del rey y las cortes ${ }^{103}$. La consecuencia es la omnipotencia parlamentaria y la irresponsabilidad del legislativo. El debate sobre el carácter ilegislable de los derechos individuales fue un episodio aislado y carente de trascendencia real.

98 A. Alcalá Galiano, op. cit., pág. 242.

99 F. TOMÁs Y VALIENTE, "Supuestos ideológicos del Código civil: el procedimiento legislativo", en La España de la restauración, VV.AA., Siglo XXI, Madrid, 1985 , págs. 369 y ss.

100 V. Santamaría Paredes, Curso de Derecho político, op. cit., págs. 175-176.

101 A. Alcala Galiano, op. cit., págs. 14 y 297.

102 J. Fco. PACHECO, Lecciones de Derecho político, op. cit., pág. 62. J. Donoso CorTés, Lecciones de Derecho político, C.E.C., Madrid, 1894, págs. 3-13.

${ }_{102}$ A. MENÉNDEZ, "Autonomía económica y codificación española", en Centenario del Código de Comercio, M. de Justicia, Madrid, 1986, págs. 60 y ss.

103 V. Santamaria Paredes, op. cit., pág. 273. 
- La consideración final que interesa resaltar es la relación, ya aludida, de subordinación entre los derechos con incidencia política y la concepción del orden público. La relativización de los derechos siempre ha estado presente en la doctrina española, declarándose los límites de los mismos en función de las necesidades que en cada momento se precisen.

El límite esencial de los derechos viene dado por el derecho del Estado que los reconoce en su vigencia y regulación, sólo en medida compatible con las exigencias de la afirmación estatal, trasladando el límite, como elemento constante, a la seguridad ${ }^{104}$.

Más que construcciones doctrinales restrictivas, pero que descansaban sobre elaboraciones conceptuales delimitadas, la doctrina española aceptó una concepción pragmática de los mismos, colocando este pragmatismo como elemento definidor de los derechos políticos.

El carácter residual que el pragmatismo tiene en la doctrina de finales del siglo XIX francés, como elemento de seguridad del sistema, que produce ciertas rupturas dogmáticas, es elevado en España a elemento básico en la doctrina de los derechos.

Esta subordinación al orden público explicará jurídica y políticamente la precariedad de la afirmación y la vida de los derechos.

\subsection{La recepción española del modelo europeo garantista de los derechos}

España se incorpora al movimiento constitucionalista europeo en momentos tempranos. De hecho, en el contexto de la expansión napoleónica se dieron los prolegómenos del constitucionalismo español. La Constitución de Bayona de 1808 pretendió ser un instrumento legitimador de la fundación de la nueva dinastía vinculada al naciente imperio francés $y$, sin embargo, inauguró el ciclo constitucional que iba a perdurar, cierto que con muchos problemas, a lo largo del siglo. Desde la perspectiva de la efectiva vigencia de este texto, la influencia del primer referente constitucional español no ha sido decisiva en la historia posterior;

104 M. Alonso Martinez, Memorias de la Real Academia de Ciencias Morales y Políticas, tomo III, Madrid, 1973, págs. 240-268. 
por ello, suele comenzarse el estudio de nuestra historia constitucional con la de Cádiz de 1812; esto no debe conducir a minusvalorar este período. En la Constitución de Bayona están presentes algunos de los rasgos del constitucionalismo del siglo XIX. No debemos olvidar que no pocos de los componentes de la Junta Nacional que participaron en la elaboración de la misma, siguieron protagonizando los sucesivos episodios constitucionales, en especial el de 1812. En cualquier caso, esta temprana incorporación española al constitucionalismo europeo, por lo que se refiere a la cuestión del reconocimiento y garantía de los derechos y libertades de los ciudadanos, lo hará desde la asunción del modelo ya en ciernes en la Constitución Francesa de 1791 y consolidado en los textos posteriores, con rasgos propios que devalúan más el valor simbólico y político de los derechos. Desde la Constitución de Cádiz hasta la de la Restauración en 1876, con diferencias de importancia, pero que no rompen el modelo. Se establece un sistema de reconocimiento infraconstitucional de los derechos, que, como hemos definido en el apartado anterior, en lo referente a los derechos de participación política y las libertades de incidencia política, suponen más una técnica de acotamiento reductivo de los núcleos reconocidos de esos derechos, que su desarrollo constitucional. La legislación ordinaria resulta ser así la fuente de regulación de los derechos ${ }^{105}$.

La relación ley-constitución, al margen de las proclamaciones formales como norma suprema de la Constitución, reproduce el esquema europeo previamente definido, que soporta la construcción jurídica de los derechos públicos subjetivos. La misma Constitución de 1812 consagra esta relación respecto a los derechos. En general, se sujeta la actividad del juez rigurosamente a la ley sobre la que no le cabe decisión alguna ${ }^{106}$. Cuando se reconocen algunos derechos que aparecen esporádicamente sancionados en el texto constitucional, si aquellos no se refieren al ámbito privado patrimonial, su ejercicio se remite a la ley. Sancionándose de esta forma un doble tratamiento respecto a los derechos, aquellos que afectan al ámbito privado patrimonial y los que lo hacen al político, considerado en sentido amplio.

Las constituciones posteriores a 1812 consagran la remisión legal del ejercicio de los derechos. La Constitución de 1869, aunque incorpora novedades importantes respecto al resto, que la singularizan especialmente dentro del panorama constitucional del XIX, no supone una ruptura con esta técnica.

105 J. M. ROMERo MORENo, «Modelos políticos, protección procesal y derechos fundamentales en.... (FALTA TEXTO).

105 Ver artículo 246 de la Constitución de 1812. 
La complementariedad código-constitución se advierte durante todo este período. No sólo se repite en los textos constitucionales, la alusión a la necesidad de elaborar códigos en sectores clave del ordenamiento, sino que éstos a menudo deben ser considerados como materialmente constitucionales en el doble sentido de abordar materias constitucionales y de contener parte de la constitución material ${ }^{107}$. La complementariedad, que es reflejo también de esa específica relación ley-constitución, viene constatada en la función que en algunos casos se otorga al código, especialmente el civil. Recuerda B. CLAVERO cómo en el primer proyecto de Código Civil español que se preparaba, se definía la condición de sirviente doméstico; ello tenía incidencia directa en las normas electorales contenidas en la Constitución de Cádiz, cuyos derechos se suspendían por el estado de sirviente doméstico ${ }^{108}$.

Los derechos declarados en las constituciones previas a la del 1869 y 76 y los más relevantes de estas últimas son básicamente reconducibles a la tutela de la propiedad, a la inviolabilidad personal en el ámbito penal y la libertad de imprenta ${ }^{109}$. Conviene recordar cómo en la construcción de los Derechos Públicos Subjetivos de JELLINEK se establecía la imposibilidad de dar a las declaraciones constitucionales en materia de derechos un valor directo que remueva los obstáculos existentes, incluso los normativos, para preservar ese espacio protegido ${ }^{110}$. Semejante efecto sólo podría otorgarse a ciertos derechos proclamados, en especial los que abolían la censura y establecian la libertad religiosa.

Son estos derechos los que mayor reconocimiento tienen en el siglo pasado. El caso de la censura previa parece claro que se expresa en términos abrogativos, sin perjuicio de las responsabilidades posteriores, donde operan las restricciones legales a la libertad de expresión. La propiedad es objeto de un doble tratamiento normativo, como derecho subjetivo, en el ámbito de las relaciones privadas intersubjetivas, y como derecho público subjetivo, cuando se contemplan las relaciones sujeto privado-Estado. En este caso, la materialización de la protección del espacio patrimonial privado frente al Estado viene dado por la prohibición de la expropiación, remitiendo su admisión excepcional a la garantía legal, que aquí opera efectivamente como tal. Los derechos personales en el ámbito penal son ante todo garantías procesales que preservan a la persona en el seno del proceso penal.

107 G. Tarello, Storia della cultura giuridica moderna, vol. I, II Mulino, Bolonia, 1975, págs. 24-5.

${ }_{108}$ B. Clavero, Evolución histórica del constitucionalismo español, Tecnos, Madrid, 1984, pág. 44; ver art. 253 de la Constitución de Cádiz.

${ }_{109}$ J. M. ROMERo MOREno, op. cit.

110 Jellinek, Sistema dei ditti..., op. cit., pág. 108. 
Se consagran así dos tipos de Derechos Públicos Subjetivos: los predicables respecto al ámbito privado patrimonial, ejemplificados en el reconocimiento del derecho de propiedad, pero que se extendían a otros derechos que adquirian autonomía propia en este campo, libertad de tráfico de mercancías y libertad de comercio, etc. Todos ellos tuvieron reconocimiento constitucional y desarrollo posterior ${ }^{111}$. Respecto a éstos, los Derechos Públicos Subjetivos se configuraron como una técnica eficaz y verdaderamente garantista. Para el resto de los derechos, esta técnica operó como mecanismo reduccionista más que de protección, como fórmula de protección del sistema, que sólo funcionaba técnicamente en el estrecho marco de su definición infraconstitucional.

El último rasgo, ahora no estrictamente normativo, de este período, por lo que respecta a los derechos, es lo que podríamos definir como el pragmatismo y alegalismo del comportamiento del poder frente a los derechos. El principio de legalidad se observa escasamente en su regulación, que se desplaza, en muchos casos, a la normativa puramente administrativa ${ }^{112}$. Además, lo que es más grave, los mecanismos de suspensión de los derechos y de declaración de estados excepcionales eran también puramente administrativos ${ }^{113}$. Junto con la arbitrariedad y precariedad de los derechos, derivado de semejante sistema de suspensión, hay que destacar la extensión cronológica y el abuso de estos procedimientos, que comprometen la historia española de los derechos y libertades. BALLBÉ ha señalado la permanente utilización de esta técnica de declaración del estado de excepción, declarado en tan gran número de ocasiones, que ha utilizado el término militarismo para calificar la realidad jurídico-administrativa española en ese siglo ${ }^{114}$.

\subsection{Los derechos públicos civiles de los ciudadanos}

\section{a) Los derechos patrimoniales}

No hace falta repetir que el derecho de propiedad se configura en el orden liberal como el ámbito de la libertad por excelencia, en la medi-

111 F. Tomás $\checkmark$ VALIENTE, Manual de historia, op. cit., págs. 414-417.

112 J. M. ROMERo MORENo, op. cit.

113 E. Garcia de EnTERRia, "Prólogo" a Orden público y militarismo en la España constitucional (1812-1983), Alianza Universal, Madrid, 1983. 1983), op. cit.

${ }_{114}$ M. BALLBÉ, Orden público y militarismo en la España constituional (1812- 
da en que se considera el instrumento de determinación individual y como consecuencia de esa centralidad; de él se hacen depender gran parte de los derechos de participación. De esta manera se produce un refuerzo de la subjetivización de los mismos, puesto que la participación política era otro instrumento de defensa propietaria en la lógica política del liberalismo del siglo XIX. Más allá de la centralidad jurídico-política de la propiedad se trata de sintetizar los caracteres de la protección constitucional de este derecho.

En la mayoría de los casos, el derecho de propiedad se contempla en las constituciones decimonónicas españolas en una doble dimensión: con un reconocimiento general del derecho y con disposiciones de alcance negativo dirigidas al Estado, que indirectamente configura el derecho. De esta forma, se refuerza el contenido garantista constitucional del derecho. La propiedad, concebida como derecho público subjetivo, se reconoce en las relaciones individuo-Estado. De las dos técnicas de articulación de los Derechos Públicos Subjetivos, a la propiedad se reservan las técnicas más efectivas. En este caso, no se declara el derecho, con independencia de su remisión a la legislación ordinaria, sino que se delimita en negativo el espacio protegido, que sólo de forma excepcional y en supuestos restrictivos puede ser traspasado.

Así, junto con la declaración del derecho o presumiendo éste, se consignan constitucionalmente la prohibición de la expropiación de bienes y de la confiscación como pena estableciendo un espacio reforzado de protección.

Junto con la propiedad como derecho ocasionalmente se reconocen otros derechos patrimoniales que resultaban necesarios para el funcionamiento del nuevo orden económico, pero esto, en la mayoría de los casos, se remite al código y a la normativa infraconstitucional previa a la codificación.

El papel central que la propiedad ha jugado, dentro de los derechos patrimoniales, en el constitucionalismo liberal se justificaba porque en sus primeros momentos la realidad económica se reconducía prácticamente a ella ${ }^{115}$ y porque este derecho estaba dotado de una potencialidad expansiva que evitaba la enunciación de su multiplicidad de contenidos.

115 M. BAssols Coma, Constitución y sistema económico, Tecnos, Madrid, 1985, págs. 111 y ss. 
Lo habitual en los ordenamientos liberales del siglo XIX era consagrar el derecho y remitir su contenido a los códigos ${ }^{116}$.

De esta forma, la doctrina coincide en señalar que el origen de parte de los derechos económicos, incluidos los consagrados inmediatamente por el liberalismo, están en el derecho de propiedad, del que son deducibles inmediatamente ${ }^{11}$. La libertad de empresa, formulada en estos momentos como libertad de industria y comercio, vendría a ser una de las formas de ejercicio del derecho de propiedad ${ }^{118}$.

Declarado el derecho de propiedad y definidas las obligaciones negativas del Estado en torno a la prohibición de expropiación, las diversas manifestaciones de su contenido descansaban en la regulación normativa inferior.

Así, desde los comienzos de la instauración del liberalismo se fueron perfilando contenidos positivos del derecho de propiedad en referencia a las libertades económicas que articularían el nuevo sistema económico.

Casi inmediatamente después de aprobada la Constitución de Cádiz, en 1813, por decretos de las Cortes de Cádiz se establecieron las libertades de comercio e industria, la libertad de precio, la libertad de circulación de bienes por el territorio nacional, así como la apertura de la libertad de comercio e industria a los ciudadanos de todas las clases, incluidos los extranjeros ${ }^{119}$. Estos decretos tuvieron continuidad y desarroIlo durante todo el siglo. La tardía codificación civil española y la normalización codificadora en el marco mercantil explica la fragmentaria protección de las libertades económicas, pero expresa la relación del reconocimiento constitucional del derecho y la definición normativa de su contenido.

La Constitución de 1812, aun careciendo de una declaración de derechos, entre los pocos reconocidos explícitamente en su largo texto se recoge no sólo el derecho, sino un cúmulo de mandatos negativos a los poderes públicos que refuerzan el derecho declarado. El modelo de 1812

116 P. Rescigno, voz "Propietà" (Diritto privato), en Enciclopedia del diritto, XXXVII, Giuffré, Milán, 1988, págs. 54-297.

117 A. BaldassarRe, Voz "Iniziativa economica privata", en Enciclopedia del diritto, XXI, Milán, 1971, Giuffré, pág. 586.

118 G. SENA, "La propietà e l'esercizio d'impresa», en Rivista di diritto industriale, 1968, vol. I, págs.109-127. págs. 415 y 416 . 
permanecerá respetado hasta 1869 , puesto que las constituciones vigentes hasta ese momento carecen de declaraciones y contemplan un tratamiento similar respecto a este derecho.

El artículo 4 de la Constitución de 1812 sitúa el marco de reconocimiento de la propiedad: "La nación está obligada a conservar y proteger por leyes sabias y justas la libertad civil, la propiedad y los demás derechos legítimos de todos los individuos que la componen".

Los mandatos negativos frente al Estado se establecen todavía como mandatos técnicamente poco apropiados. En un primer momento se establece la prohibición frente al rey: "No puede el rey tomar la propiedad de ningún particular ni corporación, ni turbarla en la posesión, uso y aprovechamiento de ella, y si en algún caso fuere necesario para un objeto de conocida utilidad común tomar la propiedad de un particular, no lo podrá hacer sin que al mismo tiempo sea indemnizado y se le dé el buen cambio a bien vista de hombres buenos" (art. 172-10). Se pretende así establecer el principio de la prohibición general de la expropiación salvo en casos excepcionales. Con posterioridad este precepto se convertirá en una prohibición general de la expropiación y la referencia a la ley como mecanismo regulador de los supuestos de excepción, perfeccionando la seguridad jurídica de los sujetos potencialmente afectados. La característica de esta regulación es que contiene una definición del derecho de propiedad con arreglo a la tradición civilista. Su pretensión obvia es preservar la propiedad en sus contornos usuales frente al poder. Este precepto fundamental, complemento del artículo 4 en el sistema de la Constitución del 12, cerraba el mecanismo de protección propietaria en la nueva situación, que era el comienzo de la andadura liberal frente al absolutismo.

Los dos preceptos señalados se completan con lo contenido en el artículo 304 en el ámbito penal prohibiendo la pena de confiscación de bienes y lo contenido en el artículo 354, que introduce el principio de libertad de circulación de bienes, con la prohibición de aduanas en el territorio nacional.

El Estatuto Real de 1834 contiene disposiciones en relación con la articulación de los poderes, básicamente el poder legislativo, en clave regresiva respecto a la Constitución de 1812. No afecta, por tanto, a la concepción constitucional del derecho de propiedad.

La Constitución de 1837 reproduce el sistema de 1812 con menos contundencia en su formulación. No se recoge una fórmula general de reconocimiento del derecho, aunque en nuestra primera Constitución la alusión era excesivamente genérica. En 1837 se sustituye por una fórmu- 
la conteńida en el artículo 10, donde con carácter general y dirigida al estado se establece otra vez la interdicción de la confiscación penal de bienes. Más importante es la prohibición de la expropiación: «Ningún español será privado de su propiedad", perfeccionando la restricción impuesta con anterioridad al rey.

En 1845, el tratamiento de este derecho se produce exactamente en los mismos términos que en 1837, ubicando en el mismo precepto la misma fórmula.

En 1869 se produce la primera transformación de importancia en el tratamiento de los derechos y libertades respecto al constitucionalismo anterior. Aparecerá por primera vez una tabla de derechos y se abrirá el debate sobre la limitación del legislador por la Constitución.

La Constitución de 1869 perfilla un derecho de propiedad protegido negativamente; siguiendo la tradición constitucional anterior, los artículos 13 y 14 configuran el nuevo sistema. En el primero se prohíbe la privación temporal o perpetua de los bienes o derechos a la perturbación posesoria de los mismos, en una formulación que continúa recordando la definición civilista de la propiedad, que se consagra así constitucionalmente. En el segundo, la prohibición de expropiación, que todavía en nuestro Código civil complementa la definición de propiedad, completa el reconocimiento constitucional de la concepción privatista de la propiedad, que aparece casi literalmente contemplada ${ }^{120}$. El traslado de lo que será el contenido del Código civil al plano de Constitución incrementa el rigor de la protección, pues establece con nitidez el ámbito protegido, con estricto mandato a los poderes públicos de abstenerse de intervenir en esa esfera. En espera de la codificación civil que cierre el círculo protector de los Derechos Públicos Subjetivos, en referencia a la propiedad, se constitucionaliza la propia definición del derecho contenida en la codificación francesa. Se pasa, pues, de la declaración del derecho a la fijación constitucional de forma estricta del contenido del mismo en los términos que incorporará la norma legal de remisión.

120 Los artículos 348 y 349 del Código civil español de 1889 corresponden a los preceptos constitucionales citados.

"Art. 348.1. La propiedad es el derecho de gozar y disponer de una cosa sin más limitaciones que las establecidas en las leyes."

"Art. 349. Nadie podrá ser privado de su propiedad sino por autoridad competente $y$ por causa justificada de utilidad pública, previa siempre la correspondiente indemnización."

A su vez, estos preceptos reproducen con ligeras alteraciones los artículos 544-545 del Código civil napoleónico y los arts 436 y 488 del Código civil italiano de 1865. 
Si algunos autores han señalado que el papel jugado por la codificación del derecho privado es el de las declaraciones de derechos y las constituciones en el derecho público ${ }^{121}$, las declaraciones contenidas en los códigos tienen una relevancia constitucional muy precisa y difícil de desconocer ${ }^{122}$.

El último episodio constitucional del siglo XIX, en 1876, el artículo 10 de esta Constitución reproduce el sistema de 1869, aunque con menor incisividad, refundiendo en un solo precepto los dos anteriores. Los elementos de la anterior: prohibición de la privación de la propiedad y de la perturbación de la posesión y la excepcionalidad de la expropiación, siempre justificada e indemnizada.

La situación final después de la Constitución de 1876 es que la propiedad es el único derecho donde la remisión legal recoge en los mismos términos la norma constitucional, habiendo operado en este aspecto la Constitución como límite al legislador o deduciéndose un Derecho Público Subjetivo de propiedad de la propia Constitución sin necesidad, de hecho, de norma legal posterior.

Similar situación existía, de forma parcial, por lo que respecta a la prohibición de la expropiación, puesto que su primera regulación por ley es de 17-1-1836 ${ }^{123}$, cuyo artículo 1 recoge esta prohibición en los términos constitucionales habituales.

\section{b) Los derechos a la seguridad y libertad personal}

Los derechos de libertad personal conforman inicialmente, junto a los patrimoniales, el cúmulo de derechos históricamente protegidos y ostentaban una relación de mutua exigencia reciproca. Articulados como derechos de abstención, afirman la autonomía del sujeto $y$, por tanto, la libertad, en torno a la cual se articulan las nuevas relaciones económicosociales.

121 G. SolARI, «Individualismo e diritto privato», reed. Torino, 1959, pág. 57, citado por Stefano RoDota, El terrible derecho. Estudios sobre la propiedad privada, Civitas, Madrid, 1986, pág. 81.

${ }_{122}$ S. RODOTA, op. cit., pág. 81.

${ }^{23}$ V. L. MONTES, La propiedad privada en el sistema del derecho civil contemporáneo, Civitas, 1980, pág. 43. 
Varios de los derechos de libertad personal son exigencia directa de la articulación del mercado, se establecen en paralela correspondencia con las facultades derivadas del derecho de propiedad u otros derechos patrimoniales, tal es el caso de la inviolabilidad del domicilio, entre otros. La libertad personal, como manifestación de la autonomía de la persona, se predica respecto del sujeto, necesariamente libre en unas relaciones intersubjetivas de intercambio.

Este grupo de derechos está contemplado con mayor o menor amplitud en todas las constituciones del siglo. Como en los supuestos anteriores, lo relevante realmente era la legislación ordinaria y ésta tardó en normalizarse. Por otra parte, estos derechos siempre han sido el núcleo más sensible a la práctica de la excepcionalidad, como normalidad política del liberalismo español del siglo XIX. Sin embargo, la codificación procesal dio buenos ejemplos garantistas hacia el final del ochocientos, que perduran en nuestro ordenamiento.

Incluimos en este grupo los derechos referidos a la inviolabilidad personal como la integridad física, la inviolabilidad del domicilio y correspondencia y el habeas corpus, así como el principio de legalidad penal que incide directamente en la libertad personal.

La entrada de estos derechos en la Constitución de 1812 es todavía limitada e imprecisa. Consagra el artículo 303 la prohibición de tormento como fórmula de obtención de confesiones en el ámbito del proceso. Los artículos 287 y 290 recogen el habeas corpus y sólo atenuadamente se esboza el principio de legalidad penal. Junto con estos derechos, se recoge la inviolabilidad del domicilio (art. 306). La salvedad a realizar es la escasa vigencia de esta Constitución, flanqueada por dos períodos absolutistas donde el reconocimiento de los derechos estaba ausente.

Las Constituciones de 1837 y 1845, como en otros, resultan coincidentes en la formulación de estos derechos. La prohibición del tormento deja de estar constitucionalizada; la inviolabilidad personal se contiene en los arts 7 y 9 en ambos textos. El artículo 9 formula, conforme al canon clásico, el principio de legalidad penal. El art. 7 incorpora, sin las prescripciones procedimentales del art. 290 de la Constitución del 12, el fundamento del habeas corpus y la inviolabilidad del domicilio, estableciéndose la habitual remisión legal en materia tan delicada.

La Constitución de 1869, como en los restantes casos, marca un punto de ruptura. La regulación de estos derechos introduce prescripciones concretas que constituyen garantías y la remisión legal es menor y más ajustada. 
La prohibición de la detención ilegal es taxativa y sólo es posible la detención por delito (art. 2). EI habeas corpus recoge normas procedimentales constitucionalizadas (arts. 4 y 12), que permitan su eficacia y limitan el margen de la regulación legal. La inviolabilidad de domicilio y de la correspondencia (arts. 5 y 7) son suficientemente precisos y sus excepciones se subordinan a la intervención judicial.

Por contra, la Constitución de 1876 recupera la regulación constitucional anterior, con menor precisión y rigor en la protección y una general remisión a las leyes para la materialización del espacio protegido; así se hace respecto a las detenciones y la inviolabilidad del domicilio y la correspondencia (arts. 4, 6 y 7 ).

\section{c) La suspensión de los derechos}

No tendría sentido en un trabajo sobre los derechos en el constitucionalismo del siglo XIX español olvidar la realidad. El dato normativo constitucional, si bien ilustrativo, no es suficiente; ni siquiera la regulación ordinaria, mucho más concluyente, sirve para reflejar la realidad en este campo. La realidad viene conformada por lo habitual y esto era el reino de lo excepcional.

Todas las constituciones con vigencia real en ese siglo preveían situaciones de excepción, con el efecto de suspender determinados derechos y garantías; sin embargo, como muestra BALLBÉ en el estudio más detallado dedicado al tema, la declaración de los mismos raramente se produjo conforme a las previsiones constitucionales.

CRUZ VILLALÓN establece con nitidez dos periodos en la historia constitucional del siglo pasado, de 1812 hasta 1869 y desde esa fecha en adelante ${ }^{124}$, aunque parece inevitable advertir un hilo conductor en todo el siglo XIX ${ }^{125}$.

Desde el punto de vista normativo constitucional, el sistema establecido en la Constitución de Cádiz servirá de referencia hasta el período revolucionario. En su artículo 308, dentro del capítulo dedicado a la administración de justicia en lo criminal, se contempla la posibilidad de sus-

124 P. CRUz VILLALón, Estados excepcionales y suspensión de garantías, Tecnos, Madrid, 1984 págs. 36-42.

${ }_{125}$ M. BALLBÉ, Orden público..., op. cit., "Introducción», págs. 20-22 y 206. 
pender algunas garantías en.materia penal, precisamente aquellas referidas a la seguridad personal. El órgano habilitado para decretar tal suspensión, cuando en circunstancias extraordinarias la seguridad del Estado lo exigiese, eran las Cortes.

En la Constitución del 1837 y 1845 , en su artículo 8 , prácticamente se reproduce el precepto de 1812, refiriéndose la suspensión a la detención, encarcelamiento e inviolabilidad del domicilio.

El sistema es de suspensión de garantías, que se produce en virtud de una situación excepcional así declarada.

En 1869 se establece un nuevo sistema de mayor rigor garantista $y$ de estricta legalidad. El art. 31 prevé la suspensión de determinados derechos y garantías tasadas estrictamente, en circunstancias extraordinarias. El procedimiento articulado es el siguiente: El marco normativo aplicable al territorio sobre el que se declara el estado de excepción está contenido en una ley de orden público, pero para su aplicación, es decir, para la declaración de ese estado, es preciso una ley. La ley declarando el estado de excepción es la llave para la efectiva operatividad de la de orden público.

La restauración introduce modificaciones de cierta relevancia, como la posibilidad de declarar el estado de excepción por el gobierno cuando las Cortes no estén reunidas. Pero podria decirse que se mantiene el sistema de 1869. La razón es que esta fórmula y su contenido garantista fueron desnaturalizadas por la pura vía reglamentaria, por lo que no hacía falta alterar el nuevo modelo constitucional, era suficiente con mantener la desnaturalización del mismo.

Hasta aquí la somera descripción de la regulación constitucional; ahora, alguna referencia a su funcionamiento.

Hasta 1837, hay que distinguir entre el trienio liberal (1820-3) y los períodos absolutistas de Fernando VII. Durante estos últimos es ocioso referirse a la suspensión de garantías precaria y no constitucionalmente reconocidas. Durante el trienio liberal, por obra de la legislación ordinaria, determinados delitos conexos con el derecho de asociación y reunión, se someten a la jurisdicción militar y a normas procesales preconstitucionales, por lo que se opera de hecho un estado de excepción restringido. La vulneración directa del art. 308 de la Constitución se dará como reacción a la actividad de los partidos absolutistas, la respuesta es 
decretar el estado de guerra por decisión gubernamental; desde el año 1922 al fin del trienio liberal, éste fue un recurso habitual, sin ninguna intervención de las cortes ${ }^{126}$.

Tras la muerte de Fernando VII y durante la vigencia de las constituciones de 1837 y 1845, se alternaron declaración de estados de sitio protagonizados por militares, en el marco de la guerra carlista, y declaraciones de estados de excepción por el gobierno. En cualquier caso, eran decisiones que se situaban fuera de las previsiones constitucionales, produciéndose una completa alegalización de la suspensión de garantías ${ }^{127}$.

Si durante este período se vivía en una situación de hecho con la Constitución de 1869, la legislación ordinaria y decisiones administrativas sobre la cuestión, pasamos a la perversión del nuevo sistema normativo diseñado desde la Constitución.

Ya hemos definido la regulación constitucional; con posterioridad a ésta y siguiendo el mandato establecido en el art. 31, se aprueba una Ley de Orden Público, el 23 de abril de 1870. Con independencia de su contenido, que se inspira en otra de 1867 , claramente restrictiva, lo que importa es el mecanismo ideado para su entrada en vigor.

La ley establecía en su artículo 1, de acuerdo con la Constitución, que las disposiciones que contenía únicamente serían aplicadas cuando se haya promulgado la ley de suspensión de garantías, que debían elaborar las Cortes, obviamente. El término de norma de reserva utilizado para calificar a esta ley es elocuente respecto a su posición en el sistema de suspensión diseñado en sede constitucional ${ }^{228}$.

La Ley de Orden Público fue aplicada sin la elaboración de las leyes de suspensión de garantías y al margen del legislativo a través de una norma puramente reglamentaria. Una circular del Ministerio de la Guerra de julio de 1870, dictada por el general Prim, anula el art. 31 de la Constitución, da instrucciones para la aplicación de la Ley de Orden Público. La interpretación grosera, que en este disposición se hace, es que la ley de suspensión de garantías, que era previa, sólo se precisaba cuando la aplicación de la de orden público implique suspensión de garantías. Entendía la circular que la constitución de tribunales militares no debía considerarse suspensión de garantías. Luego el estado de gue-

M. BALLbÉ, Orden público..., op. cit., "Introducción», págs. 20-22 y 206.

M. BALLBÉ, op. cit., , págs. 103-191.

128 M. BALlBÉ, op. cit., , pág. 207. 
rra, máxima situación de excepción prevista, podía ser declarado sin intervención de las Cortes ${ }^{129}$.

De esta forma, la Constitución de la Restauración podrá suprimir la mediación entre Ley de Orden Público y suspensión de garantías y la utilización del estado de guerra será práctica habitual para resolver los problemas de orden público ${ }^{130}$.

\section{d) Libertades de expresión y religiosa}

Es la libertad de prensa e imprenta la que ha tenido un tratamiento más homogéneo y una presencia más constante en las constituciones del pasado siglo. Los rasgos que definen su tratamiento son: en primer lugar, declaración positiva general del derecho. En segundo, prohibición de la censura previa, $y$, por último, la remisión legal, que en este caso funciona como mecanismo regresivo a posteriori, donde se delimita el ejercicio lícito del derecho. La nota característica de la regulación constitucional de este derecho es la interdicción de la censura previa; con este mecanismo se consigue el establecimiento de un espacio previo para el derecho, por lo que su reconocimiento deviene más efectivo. Todo ello sin perjuicio de la delimitación legal del mismo a través de las leyes que tendrán incidencia en el campo de las responsabilidades exigibles con posterioridad al ejercicio del derecho. Este tratamiento de la censura convertirá a la libertad de prensa e imprenta en un derecho con tratamiento formal privilegiado, aunque sin disfrutar del régimen de los patrimoniales.

La libertad de imprenta aparece en la Constitución del 12 en dos preceptos: el 131, como misión de las Cortes en el ejercicio de sus funciones, y en el 371, donde se establece el derecho según la fórmula descrita. En la Constitución del 37, este derecho se consagra en el art. 2, en similares términos. En 1845, se reitera en el art. 2 con reproducción literal del anterior. En 1869 se ubica en el 17, la prohibición de la censura se sustituye por el art. 22, ya comentado, que opera similares efectos. En este caso, el derecho reconocido es, en general, la libertad de expresión. En la restauración se vuelve a la fórmula anterior, estando contenida la libertad de expresión en el art. 13, y la remisión legal de forma general pa-

40-41.

${ }^{129}$ M. Ballbé, op. cít., págs. 208-209. También P. Cruz Villalón, op. cit., págs.

130 M. Ballbé, op. cit., pág. 210. 
ra los derechos, en el 14 . Señalado este tratamiento constitucional uniforme, como ha advertido la doctrina, la suerte del derecho se juega en la regulación legal ${ }^{131}$.

La libertad de prensa e imprenta sufre a través de la legislación ordinaria una restricción que de hecho contradice la regulación constitucional. Si formalmente desaparece la censura previa se articulan mecanismos que la sustituyen y, en cualquier caso, se produce una reducción del núcleo reconocido del derecho por vía legal notablemente severo ${ }^{132}$.

La libertad religiosa es el único derecho espiritual reconocido, y ello tardíamente, en virtud de la relevancia política de esta cuestión.

Con matices hasta 1869 no se reconoce con timidez este derecho. Las constituciones anteriores, con diferentes fórmulas, muestran el compromiso constitucional con la Religión Católica, única reconocida. La más radical es la Constitución de 1812, que contiene una declaración de confesionalidad del Estado y la prohibición de cualquier otra religión (art. 12). Las Constituciones de 1837 y 1845, en el mismo artículo, atenúan el rigor de la fórmula anterior, pero desconocen el derecho.

Es en la Constitución revolucionaria donde se garantizan los cultos no católicos y su práctica, «sin más limitación que las reglas de la moral y el derecho" (art. 21). Puede decirse que la libertad de religión no existe como Derecho Público Subjetivo durante la época anterior y que lo único no perseguible es la práctica privada de otras religiones no católicas ${ }^{133}$. La Constitución de la Restauración opera una regresión respecto al período revolucionario y sitúa la permisión de la práctica de otros cultos, "salvo el respeto debido a la moral cristiana", en el ámbito privado estrictamente: "No se permitirán, sin embargo, otras ceremonias ni manifestaciones públicas que las de la religión del Estado" (art. 11). Durante todo el siglo, únicamente en el período de vigencia de la Constitución de 1869 puede hablarse de un Derecho Público Subjetivo de libertad religiosa.

131 J. M. ROMERo, op. cit., pág. 184.

132 J. M. Romero, op. cit., págs. 189-203. Ver también A. Colomer Viadel, Sistema político de la Constitución española de 1837, Congreso de los diputados, Madrid, 1989, pág. 171.

${ }_{133}$ J. M. Romero, op. cit., págs. 206-9. 


\subsection{Los derechos políticos}

\section{a) Los derechos de asociación, reunión y manifestación}

En el primer constitucionalismo español del pasado siglo, es decir, el anterior a la Constitución del 69, estos derechos estuvieron excluidos de la Constitución ${ }^{134}$. El problema se agrava más si se tiene en cuenta que hasta la muerte de Fernando VII, el período de vigencia de la Constitución de 1812 es escasísimo, apenas 5 años. La regresión absolutista impedía poder hablar del reconocimiento de derechos que, por otra parte, no estaban constitucionalizados. Durante el trienio liberal (1820-3) de vigencia de esa Constitución, ni siquiera fue posible reconocer la existencia de Derechos Públicos Subjetivos respecto a estos derechos, puesto que el reconocimiento infraconstitucional fue inexistente. Ya en 1920, después de la reposición constitucional, en noviembre, por decreto se suprimen tanto las sociedades o juntas patrióticas como la libertad de reunión ${ }^{135}$.

Igualmente, al año siguiente se promulga la Ley de 17-4-1821, "de represión de los delitos contra la Constitución o contra la sagrada e inviolable persona del Rey Constitucional"); dicha ley se completa con un Decreto de las Cortes de la misma fecha, por el que se somete a la jurisdicción militar a los delitos anteriormente tipificados ${ }^{136}$. A través de este mecanismo, el núcleo reconocido del derecho a asociación y reunión y la propia libertad de expresión aparecen como verdaderamente residuales. Estas disposiciones continuarán en vigor, con algunos intervalos, hasta $1867{ }^{137}$. De esta forma, BALLBÉ dirá que en este período (trienio liberal), $y$ en base a estas disposiciones, se establece el excepcional modelo liberal español de orden público ${ }^{138}$, dentro del que se contenían estos derechos. Devienen por tanto derechos excepcionalizados, desde su momento de configuración legal mediante el sistema de prohibiciones.

Constitucionalmente, los textos de 1837 y 1845 no aportarán ninguna novedad respecto al ya mencionado modelo conformado en los

134 J. AsEnSI SABATER, "Un estudio sobre la aplicación del derecho de runión en el período constitucional de 1869 ", en XXII Jornadas de estudio. Los derechos fundamentales y libertades públicas, Madrid, 1993, tomo I, vol. II, págs. 1581 y ss.

135 F. Fernández Segado, El estado de excepción en el derecho constitucional español, Edersa, Madrid, 1978, pág. 78.

136 M. BALlBÉ, Orden público y militarismo en la España Constitucional, op. cit., págs. $68,74,75$.

${ }_{137}$ F. Fernández Segado, El estado de excepción, op. cit., pág. 78.

138 M. Ballbé, Orden público..., op. cit., pág. 61. 
años 1820-21 y reforzado por el Código Penal de 1822, que tendrá su continuidad en el de 1848. Los códigos remitirán los tipos delictivos al incumplimiento de las normas citadas. Este período se cierra por reseñar la última norma destacable con la Ley de Orden Público de 1867, que a afectará decisivamente a estos derechos.

Una segunda fase se abre en 1868 en los momentos de la revolución, donde por vía reglamentaria se regula el derecho de reunión y por Decreto-Ley de 20-11-1868 el de asociación. La culminación de ese proceso será la Constitución de 1869.

La totalidad de la doctrina coincide en señalar este momento como la cúspide del proceso democratizador iniciado en 1812; es en este texto donde con mayor claridad aparecen consagrados los principios de libertad y por consiguiente los derechos.

Por primera vez aparece una tabla de derechos encabezando la Constitución, entre ellos los de reunión pacífica y asociación (art. 17). La afirmación constitucional de estos derechos se matiza, limitando el alcance de una declaración general de los mismos en los artículos 18 y 19 , estableciéndose en ambos una remisión legal para su ejercicio.

El problema no debiera plantearse, puesto que la teoría de los Derechos Públicos Subjetivos incorpora esta remisión legal de la que hace depender el ejercicio lícito del derecho declarado. La alusión del artículo 18 a la sujeción del derecho de reunión a las leyes generales de policía, o la del artículo 19 a la posibilidad de disolución por ley de toda asociación cuyo objeto y medios comprometan la seguridad del Estado, responden a la fórmula de protección ya estudiada.La norma de desarrollo de las previsiones contenidas en estos preceptos es el Código Penal de 1870, que en su art. 189 tipifica los supuestos de reuniones no pacíficas con una

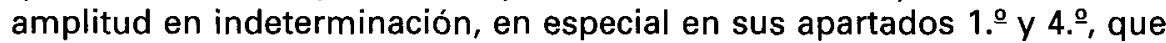
somete estos derechos al ejecutivo ${ }^{139}$. Sin embargo, en la Constitución de 1869 , el objeto central del debate constituyente respecto a los derechos y libertades fue precisamente el carácter «ilegislable» de los mismos, en expresión del constituyente del 69 . Dicho carácter se predicaba en oposición a la situación anterior y, en definitiva, comprometía la técnica de los Derechos Públicos Subjetivos, remitiéndose, en éste, a la tradición constitucional americana. Lo que estaba en discusión, en la concepción de algunos de los constituyentes, era que los derechos reconocidos no pudieran resultar disminuidos por las leyes y que en caso de colisión prevaleciera el derecho constitucionalmente declarado en su amplitud. La 
alusión al ejemplo de Estados Unidos en referencia a la supremacía de la Constitución y a la prevalencia de ésta frente a la ley, en virtud de las competencias de control de constitucionalidad conferidas al poder judicial, fue expresa y constante ${ }^{140}$; con el fin de aproximarse a este sistema de protección de los derechos se incluyó el art. 22 en el texto de la Constitución: "No se establecerá ni por las leyes, ni por las autoridades disposición alguna preventiva que se refiera al ejercicio de los derechos definidos en este título...».

¿Cuáles son, sin embargo, los requisitos para el funcionamiento efectivo del contenido del artículo 22. Estaba claro que el modelo americano, la supremacía constitucional, era, en última instancia, garantizada por el poder judicial que podía declarar la no conformidad a la Constitución, dejando inaplicada la ley. La clave era el tratamiento constitucional del poder judicial, habida cuenta del sistema de remisiones legales contenido en varios preceptos constitucionales y la genérica de suspensión por ley de los estados excepcionales ${ }^{14}$.

El tratamiento otorgado al poder judicial — «a los tribunales corresponde exclusivamente la potestad de aplicar las leyes en los juicios civiles y criminales" (art. 91) - permanecía en los términos habituales. De ese precepto no cabe deducir la facultad mencionada, en contraste con la facultad de control de los reglamentos, en aplicación del principio de legalidad (art. 92).

Será más tarde cuando el sistema político instaurado por la Constitución de 1869 desvelará sus decisiones al respecto. En la ley orgánica sobre el poder judicial de septiembre de 1870 se establecen y limitan con claridad las funciones de éste, reduciendo ésta a la estricta aplicación de las leyes. Una ley infraconstitucional sanciona definitivamente la cuestión volviendo al sistema de los Derechos Públicos Subjetivos, tal como se idea en la construcción doctrinal europea de finales del XIX $y$ se establecía, de hecho, desde los comienzos del constitucionalismo continental.

La expresión más clara de este planteamiento constitucional será, por una parte, la desconstitucionalización de la suspensión generalizada de algunos de los derechos, vulnerando el artículo 31 de la Constitución,

140 F. TOMÁs Y VALIENTE, "Los derechos fundamentales en la historia del constitucionalismo español», op. cit.

141 B. Clavero, "Por una historia constituyente: 1869, de los derechos a los poderes", en Revista del Centro de Estudios Constitucionales, 1990, n. 7, págs. 79 y ss. 
y por otra, la aprobación de un nuevo Código Penal, que reducía el espacio de licitud del ejercicio de estos derechos. En el caso del estado de excepción, éste será impuesto por la aplicación de la Ley de Orden Público de 1870 , que no respeta las condiciones constitucionales para su vigencia, sometiendo de hecho los derechos al arbitrio gubernamental ${ }^{142}$.

La Restauración borbónica, después de la frustración de la Constitución de 1869, no va a aportar novedades sustanciales a la tendencia descrita. Con todo, cabe destacar el establecimiento de un sistema de remisión legal puro para el ejercicio de los derechos, contenido en el art. 14 de la Constitución de 1876, y la supresión, en coherencia lógica con lo anterior, del contenido del artículo 22 de la Constitución Revolucionaria ${ }^{143}$.

\section{b) El sufragio}

Con toda claridad, el derecho de sufragio sólo se configura como derecho público subjetivo general en nuestro constitucionalismo en 1869, declarando este derecho y extendiendo el sufragio a la generalidad de los españoles varones. Hasta entonces, el Derecho Público Subjetivo al sufragio, nunca declarado como tal, se articulará sobre bases restrictivas y sólo respecto a limitadas capas de la población. El sufragio se limitó en base a las técnicas clásicas, continuándolo, además, con las derivadas de la configuración de una cámara alta de cariz aristocrático, que configuraba unos Derechos Públicos Subjetivos de carácter exclusivo.

La confusión nunca del todo resuelta, incluso entre quienes afirman la existencia de los Derechos Públicos Subjetivos en este campo, entre función y derechos, posibilitará la concepción restrictiva de los derechos de participación política.

Desde el punto de vista normativo constitucional, como hemos dicho, estos derechos, en especial el de sufragio no se reconocen como tales hasta 1869, hasta entonces se formula en prescripciones electorales, donde se contempla el sufragio, están pues concebidos como funciones del Estado destinadas a conformar órganos del mismo. Estaríamos frente a una concepción como la de LABAND, sufragio como derecho reflejo

142 M. Ballbé, Orden público..., op. cit., págs. 208-9.

${ }_{143}$ J. M. Romero Moreno, Proceso y derechos..., op. cit., pág. 225. También R. SÁnchez FerRIz, La Restauración y su Constitución política, F. de Derecho, Universidad de Valencia, 1984, pág. 473. 
del contenido de normas constitucionales sobre la formación de las Cámaras $^{144}$.

No tiene sentido aquí reproducir la polémica entre derechos reflejos y Derechos Públicos Subjetivos, sólo decir que las consecuencias no son las mismas. Cierto que en ambos casos se deducen facultades atribuidas a los individuos con independencia de su origen, y que en ambos casos éstos vienen establecidos normativamente Sin embargo, en la concepción del derecho reflejo, la conexión con la función es estricta y la legitimidad estatal para la reducción del mismo es evidente, al fin y al cabo, al Estado corresponde determinar las condiciones para la realización de esa función de la que es el destinatario único. Es una facultad contingente en el sentido más estricto del término.

Por otra parte, las garantías para la observancia de las facultades conferidas tienen problemas de legitimación $y$, en cualquier caso, su alcance es limitado. Aunque en algunos casos, admitido el sufragio como derecho público subjetivo, se ha llegado a similares resultados, a la contingenciación del derecho ${ }^{145}$.

En la Constitución de 1812, estos "derechos" aparecen regulados en el Título III, "De las Cortes", y vienen formuladas en los arts. 34-35-5978 , respecto al sufragio activo. El pasivo se regula en los arts 91-92. Se establece un sistema de sufragio indirecto, limitando radicalmente el número de electores en la fase final. En la primera fase, el sufragio es universal masculino. Las impugnaciones se resuelven ante la Junta de Electores (órgano político), que resuelve sin posibilidad de recursos ulteriores.

En el Estatuto Real de 1834, omitido hasta ahora por contener exclusivamente la conformación de los órganos del Estado, se instaura un estricto sufragio censitario, para la formación de unas cortes compuestas por dos estamentos, el de los próceres, designados por el Rey, y el de los procuradores, elegidos. La consideración del sufragio no es la del Derecho Públicos Subjetivo.

En las Constituciones de 1837 y 1845, regulado también en los títulos dedicados a la composición de las Cámaras, Títulos III y IV, en ambas, se configura un parlamento bicameral.

144 P. LABAND, op. cit., págs. 343-50. Ver el debate clásico producido en Alemania, sintetizado en la obra de G. JeLLINEK, Sistema dei diritti..., op. cit., y la síntesis de las distintas posiciones recogida por S. Romano, La teoria dei diritti..., op. cit.

145 S. ROMANo, op. cit., en especial págs. 84-85. 
En el Senado, los electores no designan directamente al elegido, sino que presentan una terna al Rey, que lo designa. En el Congreso de los Diputados la elección es directa. La remisión a la ley es amplia y se regula un régimen censitario estricto.

Semejante concepción del sufragio conllevaba la ausencia de mecanismos jurisdiccionales de garantía. Así, hata 1946, la normativa electoral no establecía recurso judicial a las deciones de la administración electoral sobre la inclusión en el censo. Con posterioridad, aun arbitrándose un recurso al efecto, los requisitos procesales exigidos desconectan al sufragio de la noción de Derecho Público Subjetivo.

En 1869 se proclama en la tabla de derechos constitucionales de forma solemne: "Ningún español que se halle en el pleno goce de sus derechos civiles podrá ser privado de votar en las elecciones de senadores y diputados a cortes, diputados provinciales y concejales" (art. 16). El sistema de reconocimiento de derechos de esta Constitución ha sido ya comentado, por lo que podemos decir que aquí se conforma un Derecho Público Subjetivo de sufragio ${ }^{146}$. Sistema que desaparece en la Constitución de la Restauración. Será en 1890 cuando, por ley, se instaure el sufragio universal masculino.

\section{CONCLUSIONES}

Se ha pretendido en el trabajo evidenciar tres cuestiones a las que son reconducibles las conclusiones que vamos a formular. En primer lugar, que los Derechos Públicos Subjetivos - teorización doctrinal tardíaconstituirian lo que podría denominarse como el mecanimo específico de intervención sobre la libertad por parte de los poderes públicos. En segundo lugar, los Derechos Públicos Subjetivos no tienen una articulación homogénea y general para todos ellos y por tanto tienen distinta eficacia y alcance, dependiendo en qué ámbito se expresen y, por último, que la historia de los Derechos Públicos Subjetivos, en el XIX español, tiene peculiaridades propias, pero responde, durante los períodos constitucionales, a este modelo.

Sentado lo anterior, pueden articularse nuestras conclusiones como sigue:

146 Para la regulación constitucional y ordinaria, ver J. M. ROMERo, op. cit., págs. 275-292. 
1. Puede decirse que aunque la doctrina de los derechos públicos subjetivos no se formula hasta finales del XIX, en un contexto muy específico, ésta no hace sino sancionar un determinado comportamiento del Estado liberal en la Europa continental del siglo pasado. Los Derechos Públicos Subjetivos constituyen tanto el momento doctrinal unificante como el normativo, en la vida de los derechos en el liberalismo continental.

Esta construcción es el resultado de la tensión legitimación-autoridad, que recorre el liberalismo postrevolucionario.

2. Los derechos subjetivos en su traslado al ámbito público, aun conservando su estructura formal, resultan afectados por las exigencias políticas liberales. En su traslación se opera una reducción del espacio protegido, a través de la definición legal de su contenido, que se realiza en sede legislativa y no constitucional. La ley es la fuente efectiva de los Derechos Públicos Subjetivos.

3. La necesidad liberal de diferenciar el ámbito público del privado motiva un distinto tratamiento de los derechos patrimoniales, cuando se articulan como Derechos Públicos Subjetivos (relación individuo-Estado), de los derechos politicos.

4. En el constitucionalismo español del siglo XIX existe un hilo conductor respecto al reconocimiento y tutela de los Derechos Públicos Subjetivos, que viene dado por la lógica política del moderantismo liberal, practicado de hecho durante todo el siglo, con independencia de la denominación de la corriente liberal en el poder en cada momento. El período revolucionario, simbolizado por la Constitución de 1869, no logra romper esta tendencia.

5. Sólo en el ámbito patrimonial tiene eficacia la declaración constitucional del derecho; ello se explica tanto por el alcance político de la propiedad en el sistema liberal, como por la formulación del derecho. Éste se articula en base a mandatos negativos precisos e incorpora el concepto de propiedad, que será establecido en el código, que estaba ya definido en el napoleónico de 1804 y ya presente en nuestra legislación. 
En el ámbito de los derechos de alcance político la contingenciación de los derechos es casi absoluta.

6. No puede, en ningún caso, olvidarse el recurso a las soluciones fácticas ajurídicas como mecanismo de control político, que impiden la vigencia del núcleo reconocido de los derechos declarados.

Lo que hemos definido como soluciones fácticas ajurídicas tenían un soporte jurídico notablemente precario: en la mayoría de los casos eran normas reglamentarias; en muchos casos, de la propia autoridad militar. Cuando tenían formulación legal resultaban de difícil encaje constitucional. La regulación constitucional de los estados excepcionales nunca fue respetada. 